Article

\title{
Accessory Dwelling Units as Low-Income Housing: California's Faustian Bargain
}

\author{
Darrel Ramsey-Musolf $\mathbb{D}$ \\ Department of Landscape Architecture and Regional Planning, UMass Amherst, MA 01003, USA; \\ darrel@larp.umass.edu; Tel.: +1-413-545-6619
}

Received: 16 July 2018; Accepted: 5 September 2018; Published: 18 September 2018

\begin{abstract}
In 2003, California allowed cities to count accessory dwelling units (ADU) towards low-income housing needs. Unless a city's zoning code regulates the ADU's maximum rent, occupancy income, and/or effective period, then the city may be unable to enforce low-income occupancy. After examining a stratified random sample of 57 low-, moderate-, and high-income cities, the high-income cities must proportionately accommodate more low-income needs than low-income cities. By contrast, low-income cities must quantitatively accommodate three times the low-income needs of high-income cities. The sample counted 750 potential ADUs as low-income housing. Even though 759 were constructed, no units were identified as available low-income housing. In addition, none of the cities' zoning codes enforced low-income occupancy. Inferential tests determined that cities with colleges and high incomes were more probable to count ADUs towards overall and low-income housing needs. Furthermore, a city's count of potential ADUs and cities with high proportions of renters maintained positive associations with ADU production, whereas a city's density and prior compliance with state housing laws maintained negative associations. In summary, ADUs did increase local housing inventory and potential ADUs were positively associated with ADU production, but ADUs as low-income housing remained a paper calculation.
\end{abstract}

Keywords: California; cities; low-income housing; accessory dwellings; granny flats; in-law units

\section{Introduction}

In 1982, California mandated accessory dwelling units (ADUs) as suitable housing for seniors, college students, and low-income households [1]. ADUs (also known as granny flats, in-law, or accessory apartments) are small rental units that are studios or one- or two-bedroom units. ADUs can be attached to the lot's primary housing unit (usually a single-family residence), detached in the rear yard, or located above a garage. Indeed, ADUs are appropriate for seniors because ADUs can facilitate aging in place when the unit is located on the senior's or family member's lot [2]. ADUs may also be appropriate for college students who desire short-term accommodations with limited budgets and possessions [3]. For low-income households, however, two factors undermine the suitability of ADUs as low-income housing. The first is a lack of agency oversight. The second is the efficacy of ADUs produced as regulated low-income housing units.

Regarding agency oversight, many cities responded to California's ADU mandate by modifying their zoning codes to tenure ADUs as rentals and to require ADU homeowners to record covenants attesting to the homeowner's occupancy in the ADU or the primary housing unit. However, these covenants did not obligate an homeowner to rent their ADU to any household. In addition, very few cities imposed covenants on ADUs (e.g., maximum rent, occupant income limits, and/or effective period) that would regulate the units as available low-income housing. In their survey of the ADU zoning in 87 Los Angeles County cities, for example, Mukhija, Cuff, and Serrano reported that the cities of Duarte, Santa Fe Springs, and Sierra Madre required low-income occupancy as a condition of 
the ADU approval [4]. While those authors did not verify low-income occupancy or low-income ADU production, this study has determined that the low-income conditions have been removed from these cities' zoning codes and any ADUs that were available as low-income housing no longer exist.

Regarding efficacy, California aspires to address the housing needs for households in all economic segments by requiring each city to accommodate their fair-share of a region's low-income housing needs [5]. To achieve this housing equity, California's Housing Element Law sends each city a multi-year housing allocation that identifies the city's low-income and market-rate housing needs [6]. In order to increase ADU production statewide, California allowed cities to count potential ADUs towards low-income housing needs in 2003. To be clear, potential ADUs are an estimate that is based on a planner's zoning analysis as opposed to produced units. While California has recently begun to collect longitudinal data regarding low-income housing production [7], it is not clear whether significant quantities of regulated ADUs as low-income housing exist or are available. Furthermore, no study has established any relationship between potential ADUs and ADU production. For example, from 2007-2014 California allocated 390 low-income and 282 market-rate housing needs to the City of Santa Cruz, CA, USA a city known for its progressive ADU planning [8,9]. During that time, homeowners produced 148 ADUs [10]. In terms of efficacy, this ADU production was respectively $38 \%$ and $54 \%$ of the city's allocated low-income and market-rate housing needs. These statistics indicate that ADUs did increase Santa Cruz's overall housing inventory; however, for what households were these units available? At present, Santa Cruz contains 465 legally permitted ADUs, but only 8\% (or 39) require low-income occupancy. This low proportion suggests that homeowners produced ADUs largely as market-rate units.

The confluence of a lack of oversight and the unproven efficacy of ADUs as low-income housing means that California has low-income housing units that exist on paper, but not in operation. This is the heart of California's Faustian Bargain. This compromise was necessary in order to appease cities that were resistant to increasing their low-income housing inventory. Without long-term covenants similar to those found on regulated low-income housing units (e.g., tax-credit, voucher subsidized, or publically owned), can ADUs serve as actual low-income housing? The answer is no. ADUs may increase local housing inventory and may be more affordable than other market-rate housing types due to the unit's small size; however, ADUs may not be priced for or available to low-income households [11-13]. This paper argues that for every count of potential ADUs towards low-income housing needs, a bona fide low-income unit that would have been situated in a regulated multifamily or voucher housing unit was lost. In this compromise, California and cities with exclusionary zoning win, while low-income households and cities with multifamily zoning lose.

The purpose of this research is to explore the implementation of California's ADU mandate and has five research questions that explore the conditions that influence ADU production in California cities. First, are the housing allocations proportionally similar for cities classified as low-, moderate-, or high-income? Second, to what extent do cities count potential ADUs towards overall or low-income housing needs? Third, what was the efficacy of a city's count of potential ADUs towards overall and low-income housing needs? Fourth, what conditions increase a city's probability of counting potential ADUs towards overall or low-income housing needs? Lastly, what conditions influence a city's ADU production?

After examining a stratified random sample of 57 California cities from 2006 to 2014, this study found that the housing allocations advanced a proportional fair-share intent because $60 \%$ of allocated housing needs must accommodate low-income households. However, the allocations might also concentrate the poor in low-income cities because the sample's low-income cities were required to quantitatively accommodate more than three times the quantity of low-income housing needs than the high-income cities (36,500 and 11,500; respectively). Regarding counting potential ADUs towards overall housing needs, $56 \%$ (or $32 / 57$ ) of the sample counted potential ADUs to increase overall housing inventory. Regarding counting potential ADUs towards low-income housing needs, the analysis indicates that $76 \%$ (or 13/17) of the sample's high-income cities counted potential ADUs 
as low-income housing, in contrast to $45 \%$ (or 9/20) of moderate-income cities and $25 \%$ (or 5/20) of low-income cities. Of these potential ADUs as low-income housing, none of these cities' zoning codes imposed covenants that would regulate an ADU's maximum rent, occupant income, or effective period. Regarding the efficacy of counting potential ADUs, planners counted 842 potential ADUs and 749 of those ADUs were designated as low-income housing. While the data indicates that 759 ADUs were produced for an overall efficacy of $90 \%$, none of these units could be verified as available to low-income households.

Inferentially, the analysis indicates that if a city contains a college or has high household incomes then those conditions increases a city's probability of counting potential ADUs toward overall or low-income housing needs. Regarding the conditions associated with ADU production, the analysis indicates that cities with colleges and high incomes were positively associated with ADU production. By contrast, a city's density, proportion of renters, and compliance with state housing law were negatively associated with ADU production. However, when counts of potentials ADUs are included in the model, then the counts were associated with increased ADU production, Overall, this research found that ADUs did increase the housing inventory for this sample of cities; however, it is not clear if the potential ADUs that were counted towards low-income needs actually provided housing satisfaction for low-income households because (1) the zoning codes for these cities did not maintain any low-income covenants and (2) the housing plans for these cities did not verify whether these ADUs were low-income and available to low-income households.

Following this introduction, the literature review discusses the importance of zoning in the U.S. and the intersection of ADUs with senior, innovative, and shadow housing. The background explains how California's primary housing intervention (e.g., the Housing Element Law) integrated ADUs into state housing law, the cities' subsequent responses, and then recent housing law amendments that pertain to ADUs. Next, the paper details this study's methods, data, and results. Lastly, the discussion unpacks the analysis and discusses whether ADUs can be considered low-income housing and makes suggestions regarding closing the loopholes that perpetuates California's Faustian Bargain. In this study, California's Second Unit Law and Housing Element Law operate as mandates because all cities must adhere to state housing policy. For clarity, this paper references the Second Unit Law as the ADU mandate. California makes no legal distinction between cities and incorporated towns [14]; therefore, this paper references the sample as cities. Lastly, California classifies ADUs as accessory structures. Accessory structures take the form of garages, storage units, children's club houses, artist studios, pool houses, and accessory dwelling units. This paper focuses on ADUs that are intended to satisfy housing needs.

\section{Literature Review}

This study examines the implementation and production of ADUs in California cities and this extensive literature review references aspects of California's 1982 ADU mandate as well as the scholarly promotion of ADUs for housing consumption. For seniors, ADUs can extend their independence by facilitating aging in place $[15,16]$. For renters, ADUs can provide infill housing in established neighborhoods and, when positioned adjacent to transit, facilitate a less auto-centric lifestyle [12,17]. For low-income households, ADUs with regulating covenants can provide needed low-income units [13]. However, zoning restricts ADU production. As noted by Ritzdorf, zoning is the most significant barrier to housing innovation [18].

\subsection{The Role of Zoning}

In the U.S., zoning is a legal mechanism through which cities divide neighborhoods into districts or zones; establish permitted and special uses for these zones; and regulate development by employing various development standards: building height and bulk, lot-size, setbacks, and parking [19]. In the early 20th century, many cities adopted zoning in a piecemeal fashion (e.g., Boston, MA in 1904-setbacks and bulk; Los Angeles, CA in 1909-permitted uses; New York, NY in 1916—setbacks, 
bulk, and permitted uses; [20]). However, zoning's constitutionality was questioned due to its process of adoption and impact on development. According to the U.S. Constitution's respective 14th and 5th Amendments, no state shall "deprive any person of life, liberty, or property, without due process of law" or take private property "for public use, without compensation" [21]. In 1926, two events provided resolution.

First, an advisory committee convened by the U.S. Department of Commerce issued the model State Zoning Enabling Act (SZEA) in order to ensure that zoning can be implemented "without violating property rights" [22]. Under SZEA, states would shroud zoning in the police powers (i.e., protection of a community's health, safety, morals, and general welfare) and states would delegate the police powers to cities, creating home rule. Second, the U.S. Supreme Court upheld zoning's constitutionality in the Village of Euclid vs. Ambler Realty Co. decision while also ushering in the demonization of apartments and, by extension, density. In the court's view, "very often the apartment house is a mere parasite" that infects single-family neighborhoods with "disturbing noises incident to increased traffic and business... [while] depriving children of the privilege of quiet and open spaces for play" [23]. Furthermore, "apartment houses, which in a different environment would be not only entirely unobjectionable but highly desirable, come very near to being nuisances" ([23], emphasis added). These statements became part of exclusionary arguments against density. At a minimum, density retards the development of single-family neighborhoods [24]. At its worst, density destroys idyllic single-family neighborhoods $[25,26]$.

In the immediate years after 1926, many states adopted SZEA and many cities subsequently implemented zoning ([27], Figure 1). However, Euclidean zoning begat an enduring tension between states and cities regarding autonomy and development [27-31]. Under home rule, can city residents and elected officials pursue a neighborhood idyll that excludes low-income households? Alternatively, can states override a city's prerogatives in order to provide benefits to the states' many households? In the case of ADUs as senior, innovative, and shadow housing, cities employ zoning to protect single-family neighborhoods whereas states employ zoning to increase housing options.

\subsection{ADUs as Senior Housing}

ADUs can extend the independence of seniors who are no longer self-sufficient and do not require extensive medical care [32]. A key point is a senior's or caregiver's recognition that a suburban detached home was designed for the senior's younger self [33]. However, research finds the limited adoption of ADUs for seniors due to a lack of interest and restrictive zoning. In 1981, the American Association for Retired Persons (AARP) hosted a forum to introduce Australian granny flats to American planners [34]. Since 1974, the State Government of Victoria (Australia) has rented publicly owned, small, detached, temporary structures known as granny flats to households [35]. When vacant, the state relocates the flats. In 1993, HUD piloted granny flats in its Elder Cottage Housing Opportunity (ECHO) program to assist seniors living in Iowa, Kansas, Missouri, New Jersey, and Tennessee. Although ECHO program users reported positive benefits for senior occupants, the program users also experienced high costs, variable unit quality, difficulty in moving vacant units, and restrictive zoning (e.g., design review, special or temporary uses, setbacks, density; [36]).

In order to expand senior housing options, Pollak called on planners to rethink zoning that accommodates seniors because seniors generate less political controversy [37]. To mitigate restrictive zoning, Pollak argued that ADU zoning must survive a two-part test. First, does the regulation further "a legitimate governmental purpose," and second, is there a "reasonable relation between the end sought to be achieved by the regulation and the means used to achieve that end" [37]. Pollak then advocated for flexible zoning and deed restrictions to ensure neighborhood compatibility because without a legal permit, an ADU is an illegal structure or land-use. In short, Pollak echoed Ritzdorf, who recognized that ADUs provide senior housing and generate income for seniors as well as suburban female headed households [18,38]. For example, Chapman and Howe reported that 64\% of Seattle homeowners created an ADU to earn extra income, $53 \%$ to reduce house payments, and $47 \%$ to increase 
home value [15]. With planners in mind, Ritzdorf promoted Gellen's concept of "zoning by building envelope" [39]. Rather than attach density to structures (i.e., dwelling units per acre), Gellen advocated attaching density to the lot because zoning should not "dictate a lifestyle or type of occupant" [39].

By 2006, Liebig, Koenig, and Pynoos also argued that zoning is "not in synch with ... the growing need for long-term care," and a suburban senior's desire to age in place "is compromised by the lack of adequate transportation and walkability" [40]. After surveying 32 planners from 13 states (65\% response rate), the authors determined that a family's preference for multigenerational housing was a major factor contributing to ADU production. Liebig et al. then concluded that if planners embraced a framework of family care, then zoning that promotes ADUs might be adopted due to the changing housing needs of aging baby boomers [41].

Regarding the senior interest in ADUs, Varady surveyed 225 seniors (77\% response rate) in the late 1980s and reported that only 15 seniors living in suburban detached homes or who were in poor health expressed any interest in ADUs [42]. Thirteen years later, Chapman and Howe surveyed 98 Seattle, WA, USA homeowners ( $46 \%$ response rate) and reported that seniors constructed only $27 \%$ of ADUs and were only $12 \%$ of tenants, whereas middle-aged homeowners constructed $51 \%$ of the ADUs and $64 \%$ of ADU tenants were aged 20 to 39 [15]. In the San Francisco Bay area, Wegmann and Chapple surveyed ADU homeowners ( $n=2529,13 \%$ response rate) and reported that seniors occupied only $4 \%$ of the ADUs [43]. Recently, Brown and Palmeri surveyed ADU owners in Portland, OR, USA ( $n=673,43 \%$ response rate) and reported that only $18 \%$ of owners were aged $65+$, whereas $72 \%$ were aged 35-64 [12]. Regarding ADU tenants, the authors reported that only $23 \%$ were aged $55+$, whereas roughly $74 \%$ were aged $25-54$.

Given that the literature has found that zoning restricts ADUs as senior housing and seniors have maintained low-occupancy in ADUs, are seniors a potential obstacle to ADU production? Could seniors and their desire for familiar neighborhood settings contribute to restrictive zoning? In the Phoenix, AZ, USA region, Pfeiffer transformed Orfield's suburban development typology to categorize 26 cities by their proportions of senior residents (to total residents) and their median household incomes in order to determine whether a city's character influences ADU zoning restrictions [44,45]. After examining these cities' zoning codes and interviewing planners, Pfeiffer determined that threatened cities (i.e., moderate proportion of seniors, lowest household incomes) prohibited or severely restricted ADUs because these units were seen as a nuisance. For example, one planner stated that applicants "come in for a permit for a detached garage, and the next thing you know there's a family of six living in it" [45]. The preservation cities (i.e., highest proportion of seniors, highest household incomes) limited ADUs to guesthouses that facilitated family care, but the units lacked kitchens. Lastly, the new identity cities (i.e., lowest proportion of seniors, moderate household incomes) employed ADUs to accommodate diverse housing needs (e.g., seniors, renters, and college students). For new identity cities, ADUs were integral to the city's desire for economic growth. While Pfeiffer's study provided only a descriptive analysis regarding senior residents, the analysis suggests that a city's senior population may indirectly influence the planner's implementation of neighborhood development.

In summary, this review on ADUs and senior housing needs highlights that many scholars positioned ADUs as a family-friendly solution that facilitates aging in place; however, the research does not substantiate that seniors are, in large part, ADU owners or tenants. For example, in their survey of Portland ADU homeowners, Brown and Palmeri concluded that ADUs "do house and support older persons, but apparently no more than other forms of housing" [12]. A key reason is that the construction, renting, and maintenance of an ADU can be daunting for seniors [46], whereas middle-aged homeowners may view an ADU as supplemental income. Lastly, a recurring theme in this discourse is that zoning, the local process that guides neighborhood development, also inhibits the production of ADUs as senior housing. 


\subsection{ADUs as Innovative Housing}

ADUs epitomize smart growth, new urbanism, and sustainability. Smart growth planning strives for neighborhoods that increase housing options for multiple housing needs and reduce automobile dependence in contrast to sprawling land-use that wastes natural and rural resources [47-49]. Infill ADUs implement smart growth principles because they do not expand an urban service area or growth boundary [50]. As backyard or alley homes, ADUs utilize existing infrastructure in established neighborhoods [51-53]. As attached or detached housing, ADUs transform single-family zones by increasing underutilized density [17]. As new construction, ADUs infuse older communities with new housing and residents while enabling multigenerational housing [9,54-56].

ADUs also exemplify new urbanism, which integrates land-use, pedestrian-friendly neighborhoods, reduced vehicle travel, and (ideally) economic diversity $[57,58]$. By constructing ADUs above garages or as detached units, many new urbanist developers create mixed-tenure housing on single-family lots [59]. Regarding new urbanism and low-income housing, ADUs along with small floor plans may be the only non-governmental method that provides affordable, but not necessarily low-income, housing units [13]. Heeding the smart growth and new urbanist plaudits, one can also concede that ADUs are sustainable (i.e., meeting current needs without compromising future needs) because of increased density, usage of existing infrastructure, and housing diversity $[60,61]$.

In the mid-2000s, planners and housing advocates discovered ADU nirvana in Santa Cruz, CA, USA [2,4,8,62-65]. Santa Cruz allows ADUs on owner-occupied, 5000-square-foot lots with one open ADU parking space. The city also provides seven ADU designs and grants homeowners one hour of building expert assistance. Regarding ADUs as low-income housing, if a homeowner accepts waived fees or city-sponsored financing, then the ADU is restricted to verified low-income households until the homeowner repays the fees or the loan. These policies reflect not only the spirit of California's ADU mandate but also land-use reforms advanced by Atash [66], who advocated for the removal of restrictive zoning to reduce housing costs, and Howe [67], who advocated for flexible housing designs for changing housing needs. In response to the city's flexible zoning, homeowners constructed 148 ADUs between 2007 and 2014 for a current total of 465 legally permitted units [10,68]. However, three caveats temper the success of Santa Cruz: tourism, housing demand, and home value. Santa Cruz is adjacent to the Pacific Ocean, home to UC Santa Cruz (roughly 17,300 students), and its 2010 median home value $(\$ 735,600)$ was roughly $60 \%$ higher than the state value and $292 \%$ higher than the national value.

Despite the renown of Santa Cruz, the resistance to ADUs persists because many residents fear that ADUs will harm neighborhood character and home values [4,69]. In 1986, Caves examined the zoning of San Diego, CA, USA region suburbs and found ADU prohibition [70]. National City, CA, USA declared that ADUs will increase existing blight, disrupt neighborhoods, create health and psychological problems, fiscally drain the city, exacerbate traffic, and deprive the families of adjacent single family residences of air circulation [71]. California's urban cities of San Jose and San Francisco also prohibited ADUs (citing impacts on traffic, infrastructure, and density) but recently repealed prohibition due to escalating rents [72,73]. In Illinois, Talen and Knapp examined the zoning from 37 counties and 167 cities in order to survey the adoption of smart growth policies and reported ADU prohibition in all locations [74].

A recent survey regarding opinions on ADUs ( $n=372,11 \%$ response rate) reported that City of Los Angeles, CA, USA neighborhood council members were concerned that ADUs would impact parking $(32 \%)$, density $(24 \%)$, crime $(9 \%)$, low-income renters $(6 \%)$, and safety $(6 \%$; [4]). In turn, these council members advocated for the following restrictions on ADU: stringent design standards $(62 \%)$, large lots only $(59 \%)$, consensus of adjacent property owners $(59 \%)$, attached to the main house (53\%), and on-site parking (53\%). The authors then examined the zoning from 87 suburban cities in Los Angeles County to survey ADU zoning restrictions and reported that 61 suburbs (or $70 \%$ ) required on-site parking, 42 (or 48\%) stipulated a minimum lot-size, and 27 (or 31\%) required covered parking [4]. In order to overcome ADU zoning restrictions nationally, the AARP and the American Planning 
Association (APA) created model ADU ordinances (partly based on California's ADU mandate) to influence planners in the same manner that the 1920s SZEA models influenced states $[27,75]$. The models provided three levels of development standards for fine-tuning a city's zoning: optimal (has the fewest restrictions), favorable (has modest restrictions), or minimal (may hinder production; [75]). While these standards do exhibit flexible zoning, they may also present "inefficient and duplicative government ... processes" that might impose barriers and restrict production [76].

In a bid to shift the ADU discourse to that of increased rental housing, two notable studies quantify ADU production via flexible zoning. In northern California, Chapple, Wegmann, Nemirow, and Dentel-Post examined single-family lots located within half a mile of a heavy-rail transit station in three cities (Berkeley, El Cerrito, and Oakland) and estimated that 2149 potential ADUs could be constructed under flexible zoning (i.e., less stringent lot-size, parking, and setback standards), which was $57 \%$ more than allowed under current zoning [3]. The authors extrapolated that if planners applied flexible zoning to larger areas in these cities, then 10,300 potential ADUs could be constructed, which was $138 \%$ more than allowed under current zoning. To quantify the transit area's ADU rental market, the authors randomly surveyed homeowners ( $n=515,13 \%$ response rate), and reported that $16 \%$ of these parcels contain an ADU. Of the ADUs used as housing, $49 \%$ were rent-free, and the authors determined that $90 \%$ of ADUs in Berkeley were unpermitted. To calculate the ADU rents in their study area, the authors examined Craigslist advertisements $(n=174)$ and suggested that $79 \%$ of advertised ADU rents would qualify as low-income housing. Furthermore, these potential ADUs could exceed the allocated low-income housing needs for these cities [3]. While this study clearly demonstrates how zoning restricts ADU production in urban cities, their low-income claim is tenuous because the advertised ADU rents may rely on unit deficiency (e.g., no permit) or homeowner whim (no covenants on maximum rent, occupant income, or effective period; [77]).

By 2014, Wegmann and Chapple had updated their build-out analysis and argued that zoning not only restricted ADU production but also exacerbated "a smart growth-housing development disconnect, which thwarts implementing smart growth" in urban communities ([78]; emphasis in the original). Furthermore, the placement of ADUs in high-income communities, they argued, contributed to economic diversity and fair housing. In the expanded build-out analysis (now 11.5 square miles), the authors estimated that flexible zoning would yield 8677 potential ADUs, which was $39 \%$ more than allowed under current zoning. Furthermore, $90 \%$ of these potential ADUs would qualify as low-income housing ([78], Table 4). Collectively, these and their other studies illustrate that (1) flexible zoning may increase rental housing via ADU production; (2) zoning restricts ADU production by imposing lot-size, set-back, and parking standards; and (3) ADUs can provide needed housing in urban cities that have little vacant land $[8,17,43,77]$. However, this stream of research consistently lacks significant legal measures that would secure these potential ADUs as regulated and available low-income housing.

In summary, this literature highlights that ADUs were common in most U.S. cities until the rise of Euclidean zoning, with its "strict separation of land uses" [40,79]. Under the planning frameworks of smart growth, new urbanism, sustainability, and family care, scholars position ADUs as an efficient solution that can satisfy local housing needs in land-locked urban and suburban neighborhoods. However, zoning restricts not only ADU production but also innovation in housing development, These studies suggest that changing public opinions on ADUs as well as zoning that regulates these units will be difficult; however, there is a silver lining. In 2012 Wegmann and Chapple reported that of the respondents that knew of an ADU in their neighborhood (e.g., 402 of 507 responses), $62 \%$ indicated that the nearby ADU had no negative impact on the respondent's quality of life [43]. This statistic may suggest that operational and legally permitted ADUs may be necessary to counter negative opinions. Regarding ADUs as low-income housing, very few studies have comprehensively addressed the feasibility of ADUs as low-income housing. Recently, Brown and Palmeri cautioned that "ADUs seem unlikely to be a complete solution" for providing low-income housing in tight urban markets [12]. In their Portland, OR study, the authors reported that " $80 \%$ of ADUs are going for market rates.... 
[and are] no more or less affordable than comparable apartments in multifamily developments," after accounting for the unit's size [12]. To explain why their assessment contrasted with other claims, the authors stated that "Wegmann and Chapple's ADUs were often unpermitted, while all the Portland ADUs... were permitted" [12].

\subsection{ADUs as Shadow Housing}

Since zoning restricts the issuance of ADU permits, Baer categorized unpermitted ADUs as shadow housing [79]. As defined by Baer, shadow housing does not rely on federal or state policy, per se, but arises from the confluence of restrictive zoning and a lack of subsidies that stymie low-income housing production. In this phenomena, local and non-local actors subdivide existing single-family residences or convert nonresidential structures into unpermitted units that satisfy low-income housing needs but also incite fear and apprehension among residents and city officials [79]. For example, Lang analyzed northeastern U.S. residential appraisal data, determined that ADUs were the number one item that decreased a home's value [80]. Subsequently, he argued that ADUs violate the suburban idyll because an ADU's increased density connotes an urban land-use. Alternatively, the lack of ADU permits may have negatively affected Lang's home values. Concurrent to Lang's study, Liebig et al. reported that planners in eastern U.S. cities aspired to legalize unpermitted units [40].

Research on California's urban housing markets also identifies a prevalence of shadow housing. In southern California, Chavez and Quinn randomly sampled 500 single-family homes and estimated that "about 42,000 garages [were] sheltering about 200,000 people in Los Angeles County" [81]. Improving on Chavez and Quinn's methodology, Mukhija analyzed single-family residential sales $(n=3113)$ and estimated that Los Angeles County contained roughly 25,000 unpermitted units [82]. Recently, Wegmann and Mawhorter examined informal housing in California [69]. As defined by the authors, informal housing consists of dwellings that are "built without proper buildings permits or land use approvals" [69]. The concept is an extension of colonias, a type of unpermitted subdivision that is "located on the periphery of metropolitan areas located near the border with Mexico" and the U.S. $[69,83]$. The key point for both informal housing and colonias is that homeowners, rather than builders or local governments create their housing and infrastructure.

In their study of informal housing, Wegmann and Mawhorter estimated that from 1990-2010, the California's low-density cities in coastal urban regions (e.g., Los Angeles, San Francisco) had the highest increases in informal units, with informal units produced in proportion with permitted housing units [69]. The authors also descriptively noted that as a community's household income increases, the estimate of a community's informal housing decreases ([69], Table A-1). This negative relationship could mean that high-income cities maintain effective code enforcement that halts informal housing construction, whereas low-income cities may lack this administrative proficiency [11]. Wegmann and Mawhorter encouraged planners to adopt a middle ground when quantifying shadow units (i.e., neither draconian enforcement nor disregard for health and safety); however, they did not explore the conflict that occurs when planners administer California's planning laws, legalize shadow housing, and interact with apprehensive residents and elected officials. This omission was a missed opportunity because shadow housing requires permits to ensure occupant safety.

In summary, shadow housing is borne out of restrictive zoning and deficient low-income housing subsidies. Shadow housing is found in California's tight housing markets, as noted by Chapple et al.'s determination that $90 \%$ of Berkeley's ADUs were unpermitted units [3]. Shadow housing also increases resident apprehension to ADUs as noted by Mukhija et al.'s survey in which neighborhood council members associated ADUs with crime [4]. To reduce the specter of shadow housing and increase local housing inventory, planners should modify their zoning codes in order to grant amnesty permits to these informal units. This action would integrate the legalized unit into a city's housing inventory as a rehabilitated or new ADU, a strategy that has been implemented in many California cities (e.g., Daly City, Encinitas, Los Gatos, Moraga, Ojai, Petaluma, San Carlos, and Ventura). 


\section{Background on Housing and Planning in California}

California is one of few states in the U.S. that mandates that cities address low-income housing needs and many of its housing prescriptions extend federal precedent $[27,84]$. This paper notes that the creation of low-income housing in the U.S. is always a political compromise. However, when a compromise creates additional problems, what should be done? In the case of ADUs and California, the state has recently revised state housing laws that should increase ADU production statewide. In this background section, the following sections explore the compromises embedded in federal and state low-income housing policies, California's primary housing intervention (e.g., the Housing Element Law), how California cities resist ADUs, California's ADU process and, finally, recent amendments to the ADU mandate.

\subsection{Low Income Housing in the U.S. as a Political Compromise}

California's implementation of political compromise to increase low-income housing inventory follows federal precedent. The U.S. Congress, for example, responded to the 1920s Great Depression by adopting the Housing Act of 1937. This law created the first public housing units for low-income households in the guise of a jobs bill [85]. Subsequently, these public housing units were not designed to compete with the private market or attract the middle class, but only to accommodate racially segregated low-income households. The Housing Act of 1949 set a goal of constructing 800,000 low-income units in ten years. However, this act also facilitated the refusal of mortgages to minority households, thereby restricting minority households to substandard housing in the urban core while simultaneously destroying the core with urban renewal [86-88]. The Housing Act of 1968 responded to uprisings in urban cities by prohibiting discrimination in the sale, rent, and/or financing of housing when the discrimination was based on a person's race, color, religion, sex, or national origin. However, owner-occupied buildings containing fewer than five units were exempted from adhering to these prohibitions (e.g., the "Mrs. Murphy" exemption; [89]). Lastly, the Housing Act of 1974 responded to national inflation by ceasing public housing construction and directing low-income households to private units via housing vouchers. To its credit, the government would establish a maximum rent, demand that a unit had no structural deficiencies, and require that the unit remain low-income until the voucher was terminated, the tenant relocated, or the owner opted out of participation.

Other states, in their efforts to increase low-income housing inventory, also pursue policies of political compromise. Georgia, for example, requires housing plans from cities of more than 50,000 persons [90]. This threshold also qualifies these cities for direct funding from the U.S. Department of Housing and Urban Development (HUD). In order to reduce bureaucratic burden, Georgia allows these cities to substitute their HUD plans for the required housing plan [91]. Due to this compromise, it is not clear whether HUD or local planners are directing Georgia's local housing policies [92]. In 1999, Wisconsin Smart Growth Law required housing plans from all cities and towns if these jurisdictions implemented zoning [93]. By 2015, nearly 1500 housing plans had been created [94]; however, Wisconsin's reluctance to define housing needs may allow its jurisdictions to zone their land in ways that might actually limit housing types and exclude residents by household income [95]. Since 2005, Illinois requires that all cities ensure that $10 \%$ of their housing inventory is affordable to low-income households. Non-compliant cities must create housing plans that include objectives that will increase low-income housing inventory [96]. However, many cities claimed that the law did not apply to them due to Illinois' generous grant of home rule [97].

\subsection{California's Housing Element Law and the Integration of ADUs}

California's positioning of ADUs as low-income housing is surprising, given the state's progressive housing policies. In 1967, California adopted the Housing Element Law and required all cities to accommodate housing demand [6]. The state employs a fair-share regional housing allocation 
as an intervention that redistributes low-income housing needs within a region. This multi-step intergovernmental process involves the state's housing agency-the Department of Housing and Community Development (CAHCD), the regional councils of governments (COGs), and the local cities. The general process is as follows.

First, every five years CAHCD estimates California's statewide housing needs for current and future residents. Second, to accommodate equitable housing consumption for all households, the COGs allocate individual housing needs to all member cities so that households in all economic segments can find suitable housing within their respective region. The allocation implements housing equity (i.e., fair-share) by stratifying housing needs by household income: very low (i.e., $0-50 \%$ of HUD's median family income), low (51-80\%), moderate (81-120\%), and above moderate (121\% and higher, See Supplementary Table S1). Due to California's home values, the very low-, low-, and moderate-income categories constitute low-income housing, while the above-moderate category is market-rate housing [98]. Third, the cities create housing plans that incorporate and implement the allocation by quantitatively specifying how low-income housing and market-rate needs can be satisfied with construction, rehabilitation, or subsidy preservation programs over a 5- to 8-year period. Lastly, CAHCD assesses every housing plan to ensure that the plan's goals, policies, and programs comply (i.e., compliance) with state law. California adopted these measures due to its historically constrained housing market. From 1960 to 2010, California's median home value increased by roughly 324\% to $\$ 405,800$, whereas the U.S. equivalent increased by $149 \%$ to $\$ 187,500$ (e.g., all dollars are constant to year 2009).

However, there are two loopholes in this process. First, section 65584.04(d) of the Housing Element Law identifies a 10-point criteria that should be considered when COGs devise the fair-share regional housing needs allocation. These criteria include the following regional conditions: jobs and housing balance; development constraints (e.g., water and sewer availability, land availability, land and agricultural preservation); distribution of household growth assumed for regional transportation plans, market demand; loss of assisted housing units; high housing cost burdens; housing for farm workers; and housing needs generated by the presence of a university. While these criteria are important, California does not set priorities. For example, should the housing needs of universities have more importance than those of large families, seniors, or the homeless? Should housing growth be directed to cities with low land costs even though the existing public transit may be insufficient for low-income households? These important discretionary decisions are decided by the agency that devises the housing allocations.

Second, the scholarship on the efficacy of California's Housing Element Law provides "opposing conclusions about the effectiveness of the California model" [99,100]. California evaluates its fair-share strategy by enumerating the quantity of cities with compliant housing plans, as opposed to enumerating constructed low-income and/or market-rate housing units. In 1991, only $11 \%$ of cities maintained compliant housing elements. By 2010, compliance peaked at 90\% of cities [101]. Regarding the relationship between compliance and housing production, in the early 2000s Lewis determined that housing plan compliance had no relationship with a city's housing production or ratio of multifamily units to total housing units, but compliant cities issued more multifamily permits than non-compliant cities [102,103]. Recently, Ramsey-Musolf examined cities in the Los Angeles and Sacramento regions and determined that compliant cities were associated with a $2.3 \%$ increase in low-income housing production (as identified by the housing plans) relative to non-compliant cities [104]. By contrast, compliant cities were associated with a $0.22 \%$ decrease in annual housing production (i.e., permits) relative to non-compliant municipalities. However, these associations are limited to the purposive sample $(n=53)$.

Regarding California's positioning ADUs as low-income housing, the seeds of California's Faustian Bargain began with federal devolution. In the early 1980s, Reagan's presidential administration set out to reduce federal expenditures and drastically cut HUD's budget authority by more than 70\% [105]. This action fomented a crisis in low-income housing subsidies [106,107]. 
In response, California's legislature declared "that there is an [sic] tremendous unmet need for new housing to shelter California's population. The unmet housing needs will be further aggregated by the severe cutbacks in federal housing programs" ([1], Section 1(a), circa 1982). Consequently, in 1982, California mandated that all cities permit ADUs in residential zones to address the unmet housing needs of renters, seniors, and low-income households and to avoid providing state housing subsidies ([1], Section 1(d)(1), circa 1982).

\subsection{Cities Hinder ADU Production with Zoning}

After California adopted the ADU mandate in 1982, many California cities interpreted ADUs as an encroachment on local autonomy and employed zoning standards to resist the state's intervention and to protect neighborhood character. One notable example is the City of Pasadena, CA, USA. In 2003, Pasadena modified its zoning code to constrain ADU production by restricting ADU approvals to no more than 20 per year and setting a cumulative maximum of 200 ADUs in the city [108]. In other cities, additional zoning standards were used to control ADU production (e.g., unit size, minimum distance between ADUs, etc.). From the ADU discourse, the three most restrictive standards are lot-size, parking, and approvals [3,4].

Regarding lot-size, every California city must establish a minimum lot-size for the orderly creation of subdivisions [109]. To hinder ADU production, cities require the subject lot to exceed the zone's minimum size (e.g., requiring 10,000 square feet in a 5000 square-foot zone) or maintain a minimum size. Returning to Pasadena, for example, the city allows ADUs on single-family lots $(n=22,594)$ that are not located in either a landmark or hillside district $(22,594-8431=14,163)$ and are greater than 15,000 square feet $([110,111], 14,163-11,961=2202)$. With this lot-size standard, Pasadena has reduced lots eligible for ADUs by roughly 90\% [108]. Regarding parking, many developers decry excessive standards because parking construction increases costs [112,113]. To hinder ADU production, cities will require homeowners to enclose ADU parking. In 2003, Pasadena required that ADUs maintain two enclosed parking spaces regardless of whether the ADU is a studio, a one-bedroom, or a two-bedroom unit, for example.

Regarding approvals, researchers note that uncertainty (e.g., time to approval, impact fees, or conditions of approval) may increase developer anxiety and decrease project feasibility [114,115]. From 1982 to 2002, cities could employ conditional use permits (CUPs) to restrict, for example, each ADU's occupancy (i.e., seniors, family members, and household size), design, parking, tenure, windows to reduce privacy invasion, rents, and/or inspections. In order to ensure that only homeowners developed ADUs and occupied the sites, many cities required that homeowners record a deed restriction as a condition of approval. In 2002, California revised the ADU mandate to prohibit CUPs for ADUs, but not deed restrictions. Deed restrictions allow cities to retain discretionary authority because they tie the ADU approval and homeowner's behavior to the property's deed.

Unlike building permits, which are applied-for, inspected, and then finalized, deed restrictions govern the behavior of current and subsequent homeowners by tying the operation of the ADU to the property's title. Furthermore, deed restrictions may interfere with the homeowner's property rights (e.g., develop, refinance, or sell the property; [116]). One can argue that cities can justify deed restrictions by claiming that homeowners are developing their properties differently from neighboring residences and creating potential nuisances, such as noise or parking. However, nuisances can be addressed by notifying a city's code enforcement staff $[117,118]$. With deed restrictions, cities treat homeowners with the same scrutiny of corporate developers, even though an ADU is only one unit.

\subsection{California's ADU Process and Questionable Evidence}

After nearly 20 years of resistance to the 1982 ADU mandate, California modified the Housing Element Law and the ADU mandate to incentivize ADU production in 2002 and subsequently created its Faustian Bargain. This revision established a four-part process that sustains California's aspiration to increase low-income housing inventory (without providing subsidies) and allows cities 
to retain local autonomy (via zoning). First, California allowed cities to count ADUs towards allocated low-income or market housing needs based on the following criteria: ADUs that were recently permitted or potential ADUs that could be constructed on eligible lots ([6], § 65583(b)(2)). To be clear, a potential ADU is a paper calculation that is based on zoning. Second, California clarified the effective period for any proposed low-income housing unit that would receive a public subsidy (e.g., rehabilitated units-20 years, acquired units-30 years, and preserved units (extended subsidies)—40 years; [6] § 65583.1). For ADUs, if a homeowner accepts waived fees from the city, then the waiver constitutes a public subsidy. Third, California directed CAHCD to determine the feasibility of potential ADUs (e.g., potential production, low-income or market-rate income category) by assessing each city's current ADU production, resources, and incentives when the agency reviews the city's housing plan. Lastly, and most importantly, California also allowed CAHCD to consider "any other relevant factors, as determined by the department" when the agency assesses a city's housing plan and the city's count of potential ADUs ([6], § 65583.1).

In this 2002 revision, California linked housing needs, zoning, and ADUs and received four benefits. First, California receives an increase in rental housing for every constructed ADU. Second, counting potential ADUs enumerated in housing plans validates California's complex multiyear regional housing needs allocations. Third, counting potential ADUs allows cities to aspire to satisfy local housing needs with local housing production facilitated by their local housing plans and zoning. Lastly, counting potential low-income ADUs allows the cities and the state to check-the-box on providing housing equity.

By contrast, the 2002 revision dampens low-income housing production. If cities count potential ADUs towards low-income housing needs, then these cities no longer need to earmark or compete for subsidies for these units, as homeowners bear construction costs. Therefore, any external federal or state incentive for low-income housing has lower leverage. Next, for cities that resist density as well as low-income housing, counting potential ADUs towards low-income housing needs reduces any pressure to zone land for future multifamily units that might house low-income households and might increase local needs for local social services. Alternatively, cities with multifamily zones must pick up the regional slack for low-income and regional housing needs because ADUs are single units in low-density neighborhoods.

Regarding the role of CAHCD as California's housing agency, the 2002 revision requires that CAHCD determine whether ADUs will serve low-income households. On the other hand, California allows CAHCD to accept questionable evidence. The following examples illustrate the persistence of deficient state and city oversight and deficient production of ADUs as low-income housing. In 2010, the City of Malibu, CA, USA's median home value (\$2.34 Million) was roughly $476 \%$ higher than California's value [119]. For its 2008-2014 housing plan, Malibu received an allocation of 188 low-income housing needs. In response, Malibu created an affordable housing overlay and identified three parcels that could accommodate 158 new low-income units. For the remaining 30 units, Malibu counted potential ADUs as low-income housing to be located citywide. Trancas PCH LLC, a developer with eight acres of buildable land, applied for inclusion into the overlay and included potential ADUs as low-income housing [120,121]. Malibu denied the application and Trancas sued in court.

After reviewing considerable housing data, California's Court of Appeal declared "there is no evidence ... [that ADUs] in Malibu are available to be rented" to low-income households, especially given that its housing plan states that "it is not possible for low-income households to find" rental housing without overpaying [122]. The court then chastised CAHCD for failing to "address [Malibu's] flawed assumption that [ADUs] would be available" to low-income households [122]. Malibu assumed "that about three-quarters of [low-income ADUs] will be made available with no rent charged" ([123], Supplementary B, p. 2). This assumption was questionable. For example, Brown and Palmeri surveyed ADU homeowners and determined that "rents of zero are very unlikely to be made available to strangers" [11,12]. Finally, the court vacated Malibu's 2008-2014 housing plan and declined deference 
to CAHCD's approval of Malibu's 2013-2021 housing plan, which assumed that 15 potential ADUs as low-income housing would be available during the planning period [122].

Another example of deficient agency oversight and ADU production can be found in the Town of Moraga, CA, USA. In 1989, a developer proposed to create 263 residential lots (i.e., Palos Colorados) on 210 acres [124]. By 1996, Palos Colorados consisted of 146 residential lots on 460 acres and a golf course [124]. Due to considerable opposition from Moraga residents and the adjacent Town of Lafayette, CA, USA in 2009 the developer revised Palos Colorados to consist of 123 lots on 460 acres [125]. In 2010, CAHCD approved Moraga's 2007-2014 housing plan, which counted 30 potential ADUs towards low-income housing needs in Palos Colorados [126]. However, Palos Colorados' first permit was issued in 2016 [127]. Thus, for nearly fifteen years, 30 low-income housing units existed only on paper. Another example is the City of San Ramon, CA, USA. In its 2007-2014 housing plan, San Ramon counted 50 potential ADUs towards low-income housing needs [128]. In one particular planning case, San Ramon required that an approved subdivision (i.e., Old Ranch Summit) provide nine potential ADUs towards low-income housing needs. However, the subdivision's covenants (as approved by San Ramon) declared that the homeowners were under no obligation to rent their ADUs [129]. In San Ramon's subsequent 2015-2023 housing plan, the city again counted 50 potential ADUs towards low-income housing needs [130].

The City of Folsom, CA, USA is another example. For its 2007-2014 housing plan, Folsom counted 50 potential ADUs towards low-income housing needs but only eight ADUs were constructed. However, the city does not provide any information regarding the ADU occupant incomes or effective period [131]. Folsom, it should be noted, has been sued twice over its exclusionary housing policies [132,133]. Lastly, is the City of San Marcos, CA. From 1999-2005, ten ADUs were constructed; however, San Marcos counted 40-50 potential ADUs towards low-income housing needs in its 2005-2010 housing plan [134]. Eventually, thirteen ADUs were constructed, but San Marcos provided no information regarding these units' maximum rent, occupant income, or effective period [135].

Even though any ADU that was constructed in the previously mentioned cities would increase local housing inventory, it is not likely that any of these ADUs can be regulated as low-income housing. The zoning codes for these cities restrict ADU tenure (rental only), not maximum rent, occupant income, or effective period. Unless the city explicitly describes the nature of any low-income covenant, a city risks homeowner claims of "regulatory takings" due to insufficient due process and/or the imposition of low-income rent may render the ADU fiscally unfeasible [21,136,137].

\subsection{Recent Amendments to Increase ADU Production}

Due to the continued resistance to ADUs, in 2016 California adopted three laws that removed four significant zoning restrictions [138-140]. First, starting in 2017, any zoning that prohibited ADUs was invalid. Second, ADUs will not require separate utilities. Third, ADU parking is not required if the proposed unit is located in an existing residence, a historic district, within one block of a car share program, or within $\frac{1}{2}$ mile of public transit. Lastly, ADU parking is allowed in setbacks unless this standard is prohibited citywide. In response to these flexible standards, the City of Oakland received 247 ADU applications in 2017, a 648\% increase over its 2015 total [141]. Just as dramatic, the City of Santa Barbara received over 200 ADU applications in 2017, in contrast to the 25 ADUs approved over the past 25 years [142]. While these laws should increase ADU approvals, California adopted an emergency law that might have a larger impact on ADU production [143].

Assembly Bill 2406 creates and defines a "junior" ADU (JADU) as a housing unit that is enclosed within an existing single-family residence. JADUs require a separate entrance, a minimal kitchen (e.g., no gas utility), a deed restriction certifying homeowner occupation, and cannot exceed 500 square feet. Under these standards, homeowners can transform a first-floor master bedroom suite into a JADU with minimal renovation. Furthermore, if the property owner is a government agency, housing organization, or land trust, then the deed restriction is waived. Collectively, these amendments should 
penetrate the phalanx of local zoning restrictions and position California as the bellwether of statewide ADU planning. JADUs, which formalize informal housing arrangements [69], are of particular note.

In summary, California has allowed ADUs as a local strategy to satisfy local housing needs since 1982. In response, many cities viewed ADUs as a threat to autonomy and adopted ADU prohibitions or zoning restrictions in order to claw back authority [144]. Due to the 2002 revision of state law, many cities began counting potential ADUs towards low-income housing needs, but CAHCD's approval of this count may not be supported with evidence indicating that (1) a city's zoning code will ensure that these potential ADUs will be regulated as low-income housing or (2) the potential ADU production will be double or treble a city's historic ADU production. While it can be argued that counting potential low-income housing units in multifamily zones does not guarantee that such units will be built, any completed low-income multifamily project will maintain financial contingencies (i.e., state or federal subsidies, tax credits) that impose low-income occupancy and effective period at the project's permit issuance. Given the examples of Malibu and other cities, many cities have counted potential ADUs towards low-income housing needs in order to comply with California's housing laws. However, due to a lack of agency oversight and deficient ADU production, these cities may have shifted low-income households to other communities. Lastly, in 2016 California revised state law to jump-start ADU production. In the case of JADUs, California has embedded deed restrictions into state housing law. These recent revisions will indeed increase ADU production; however, it remains to be seen whether these ADUs will increase actual low-income housing inventory.

\section{Methods and Data}

This study examines California's ADU mandate to explore what conditions influence ADU production in California cities and has five research questions. First, are the fair-share housing allocations proportionally similar for cities classified as low-, moderate-, or high-income? Second, to what extent do cities count potential ADUs towards overall or low-income housing needs? Third, what was the efficacy of a city's count of potential ADUs towards overall or low-income housing needs? Fourth, what conditions increase a city's probability of counting potential ADUs towards overall or low-income housing needs? Lastly, what conditions influenced each city's ADU production? The following discussion explains this study's context, research design, units of analysis, sampling frame/sample, tests, and data.

Contextually, ADUs interface with the Second Unit Law and the Housing Element Law because both laws endeavor to increase housing supply by influencing local government behavior. The Second Unit Law positions ADUs as suitable housing for seniors, college students, and low-income households. The Housing Element Law's requires cities to modify their internal density (via the fair-share housing needs allocations) and allows cities to count potential ADUs towards low-income or market-rate housing needs. Since more than 530 local governments must prepare housing plans that require a CAHCD assessment, CAHCD staggers each plan's effective period by its home region: the Los Angeles region, 2006-2014; the Sacramento region, 2006-2013; the San Diego region, 2005-2010; and the San Francisco region, 2007-2014. In response to these overlapping effective periods, this research employs a longitudinal design, with a period of study (2007-2014) that observes the initial integration of ADUs into the required housing plans.

The units of analysis are cities, of which California has 494 . Due to the required data and limited resources, this study employed five criteria from both laws to create a sampling frame of 255 cities and subsequent sample. First, the study examined low-income housing production in which CAHCD, COGs, and cities participate. In regions without a COG, CAHCD creates the housing allocation. Second, regions with urban central cities were examined as opposed to entirely rural regions. Suburbs in urban regions may resist multifamily zoning in order to reduce the potential relocation of urban low-income households and their social service needs [145]. Third, cities that existed at the inauguration of CAHCD's compliance reports in 1990 were examined. Prior to 1990, there is no reliable data. Fourth, twelve cities with populations greater than 200,000 were eliminated in order to focus on California's 
small- and medium-sized cities. California classifies its cities as general law or charter. The former are subject to state law, while the latter enjoy broad autonomy regarding adherence to state planning laws [146]. Eleven of the eliminated cities are charter cities (Supplementary Table S2). In addition, 97\% of California's cities maintained populations of less than 200,000 in 2000. Lastly, each city must have its 2007-2014 and 2015-2023 housing plans. The former indicates counts of potential ADUs, while the latter indicates ADU production. The resulting sampling frame consisted of cities from the following urban regions: Los Angeles $(n=140)$, Sacramento $(n=14)$, San Diego $(n=16)$, and San Francisco $(n=85)$.

The stratified random sample consists of 57 cities that reflect low-, moderate-, and high-incomes as categorized by each city's 2000 median household income (MHI). When the COGs devised the fair-share housing allocation for the 2007-2014 planning period, they examined year $2000 \mathrm{MHI}$ (and other data) to quantify low-income and market-rate housing needs. After plotting the sampling frame's standardized MHIs, clusters of cities appeared near $-0.5,+0.25$, and +1 values. A comparison of the standardized clusters from the population and sampling frame discerned complementary patterns (Supplementary Figure S1). Based on these distributions and the influence of Pfeiffer's research on city character and household incomes, the -0.5 to -0.26 bin was categorized as low-income cities $(n=74)$, the +0.25 to +0.49 bin as moderate-income cities $(n=22)$, and the +1.0 to +1.9 bin as high-income cities $(n=17)$. The sample consists of 20 randomly selected cities from each of the low- and moderate-income categories and all 17 cities from the high-income category. The sample's regional distribution is Los Angeles (24 out of 140 cities), Sacramento (4 out of 14 cities), San Diego (five out of 16 cities), and San Francisco ( 24 out of 85 cities). Table 1 identifies the sample by group, income, and allocated housing needs (circa 2007-2014).

Table 1. Sample ranked by year 2000 median household income. California's 2000 Median Household Income was $\$ 47,493$. The quantity of housing needs covers the period of study (2007-2014). Sources: ABAG, SACOG, SCAG, SANDAG, and [147]. Notes: LIH = low-income housing, MR = market-rate.

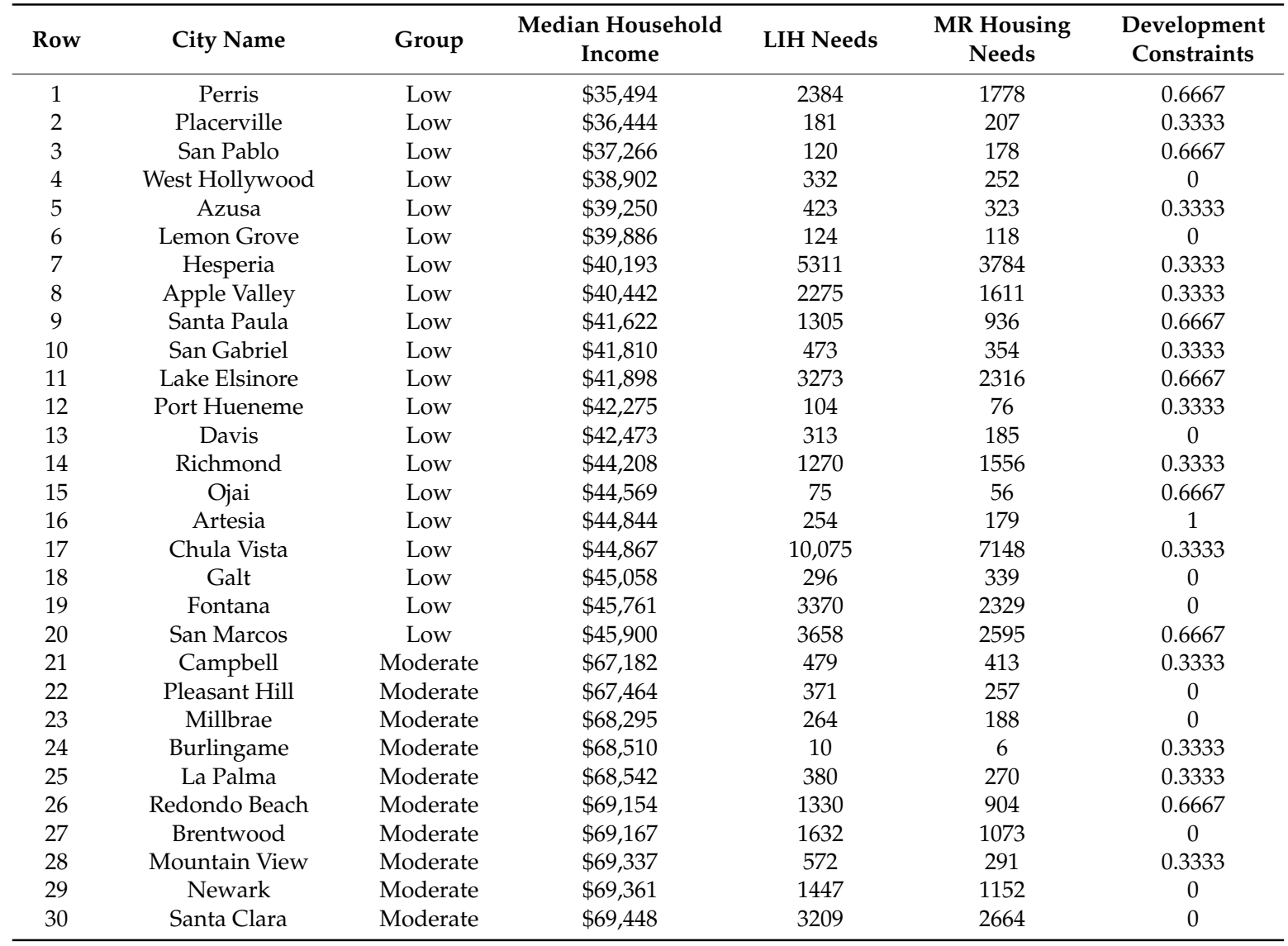


Table 1. Cont.

\begin{tabular}{ccccccc}
\hline Row & City Name & Group & $\begin{array}{c}\text { Median Household } \\
\text { Income }\end{array}$ & LIH Needs & $\begin{array}{c}\text { MR Housing } \\
\text { Needs }\end{array}$ & $\begin{array}{c}\text { Development } \\
\text { Constraints }\end{array}$ \\
\hline 31 & Fountain Valley & Moderate & $\$ 69,789$ & 278 & 189 & 1 \\
32 & Laguna Hills & Moderate & $\$ 70,188$ & 5 & 3 & 0.6667 \\
33 & Simi Valley & Moderate & $\$ 70,370$ & 2053 & 1330 & 0.3333 \\
34 & Beverly Hills & Moderate & $\$ 70,932$ & 259 & 178 & 0.3333 \\
35 & San Anselmo & Moderate & $\$ 71,600$ & 66 & 47 & 0 \\
36 & Poway & Moderate & $\$ 71,673$ & 736 & 505 & 0.3333 \\
37 & Pacifica & Moderate & $\$ 71,820$ & 161 & 114 & 1 \\
38 & Solana Beach & Moderate & $\$ 71,974$ & 77 & 53 & 0.3333 \\
39 & Cerritos & Moderate & $\$ 73,000$ & 56 & 38 & 0.6667 \\
40 & Folsom & Moderate & $\$ 73,133$ & 2649 & 952 & 0 \\
41 & San Carlos & High & $\$ 88,349$ & 351 & 248 & 0.6667 \\
42 & Yorba Linda & High & $\$ 89,623$ & 1243 & 796 & 1 \\
43 & Palo Alto & High & $\$ 90,393$ & 1874 & 986 & 0.6667 \\
44 & Pleasanton & High & $\$ 90,827$ & 196 & 96 & 0.3333 \\
45 & Mill Valley & High & $\$ 90,921$ & 2524 & 753 & 0.6667 \\
46 & Los Gatos & High & $\$ 94,259$ & 376 & 186 & 0.3333 \\
47 & Foster City & High & $\$ 95,223$ & 285 & 201 & 0.3333 \\
48 & San Ramon & High & $\$ 95,888$ & 2629 & 834 & 0 \\
49 & Moraga & High & $\$ 97,843$ & 172 & 62 & 0.6667 \\
50 & Cupertino & High & $\$ 100,414$ & 813 & 357 & 0 \\
51 & Manhattan Beach & High & $\$ 100,762$ & 545 & 350 & 0 \\
52 & Ross & High & $\$ 102,015$ & 19 & 8 & 0 \\
53 & Lafayette & High & $\$ 102,079$ & 270 & 91 & 0.3333 \\
54 & Tiburon & High & $\$ 106,564$ & 84 & 33 & 0 \\
55 & Rolling Hills Estates & High & $\$ 109,531$ & 16 & 10 & 0.3333 \\
56 & La Canada Flintridge & High & $\$ 109,874$ & 143 & 92 & 0.6667 \\
57 & Villa Park & High & $\$ 116,547$ & 7 & 4 & 0 \\
\hline
\end{tabular}

The first research question (Are the fair-share housing allocations proportionally similar for cities classified as low-, moderate-, or high-income?) was answered with a descriptive analysis of each city's 2007-2014 fair-share housing allocation, as determined by the COGs. This analysis also references the collective fair-share housing allocation for the urban regions. The second research question (To what extent do cities count potential ADUs towards overall or low-income housing needs?) was answered with a descriptive analysis of each city's 2007-2014 quantified objectives. As determined by each city's planners, the quantified objectives indicate counts of potential ADUs by quantity and by income (e.g., low-income or market rate; [6], § 65583(b)(2) and (c)(1)). This analysis created the variable potential ADUs. The third research question (What was the efficacy of a city's count of potential ADUs towards overall or low-income housing needs?) was answered with a descriptive analysis of each city's 2007-2014 quantified objectives and the evaluation of the 2007-2014 housing plan that was located in the 2015-2023 housing plan.

The fourth research question (What conditions increase a city's probability of counting ADUs towards overall or low-income housing needs?) was answered with logistic regression. The response variable $A D U s Y / N(0$ or 1$)$ measures whether the quantified objectives identified counts of potential ADUs. The response variable $A D U$ s as $L I H$ ( 0 or 1$)$ measures whether quantified objectives identified potential ADUs as low-income housing. The fifth research question (What conditions influence a city's ADU production?) was answered with negative binomial regression. The response variable ADU Production measures the quantity of ADUs constructed during 2007-2014, as per the 2015-2023 housing plans.

As count data, ADU Production has no negative values and is not normally distributed. Due to these conditions, the study employed negative binomial regression (rather than quasi-Poisson and zero-inflated Poisson) because of its goodness of fit measures (i.e., AIC, log likelihood), exponential and standardized coefficients, and usage in other planning studies $[148,149]$. The results discussion also includes the predicted probability (i.e., logistic) or expected counts (i.e., negative binomial) of selected variables. In both cases, each subject variable's probability, or expected counts, was calculated by using the subject variable's values (i.e., if dichotomous: minimum, maximum; if continuous: the minimum, 
mean, maximum) and the means of the other predicting variables multiplied by the model's coefficients. The regression tests did not indicate multicollinearity (variance-inflation statistics <3; [150]). Table 2 lists the research questions, methodology, data, and primary data sources.

Table 2. The study employs five research questions and the table lists of the research questions, methodology, data, and primary data sources. Notes: ADU = accessory dwelling unit, LIH = low-income housing, $\mathrm{Y} / \mathrm{N}=$ yes or no.

\begin{tabular}{|c|c|c|c|}
\hline Research Question & Methodology & Data & Data Source \\
\hline $\begin{array}{l}\text { Are the housing allocations } \\
\text { proportionally similar for } \\
\text { cities classified as low-, } \\
\text { moderate-, or high-income? }\end{array}$ & Descriptive Analysis & $\begin{array}{l}\text { Fair-Share Housing } \\
\text { Needs Allocations }\end{array}$ & 2007-2014 Housing Plans \\
\hline $\begin{array}{c}\text { To what extent do cities count } \\
\text { potential ADUs towards } \\
\text { overall housing needs or as } \\
\text { low-income housing? }\end{array}$ & Descriptive Analysis & $\begin{array}{c}\text { Quantified Objectives } \\
\text { (Variable: } \\
\text { Potential ADUs) }\end{array}$ & 2007-2014 Housing Plans \\
\hline $\begin{array}{l}\text { What was the efficacy of a } \\
\text { city's count of potential ADUs } \\
\text { towards overall and } \\
\text { low-income housing? }\end{array}$ & Descriptive Analysis & $\begin{array}{l}\text { A: Fair-Share Housing } \\
\text { Needs Allocations, } \\
\text { Quantified Objectives; B: } \\
\text { Evaluation of the } \\
\text { 2007-2014 Housing Plans }\end{array}$ & $\begin{array}{l}\text { A: 2007-2014 Housing } \\
\text { Plans; B: 2015-2023 } \\
\text { Housing Plans) }\end{array}$ \\
\hline $\begin{array}{l}\text { What conditions increase a } \\
\text { city's probability of counting } \\
\text { potential ADUs towards } \\
\text { overall housing needs and as } \\
\text { low-income housing? }\end{array}$ & Logistic Regression & $\begin{array}{l}\text { Response Variables: } \\
\text { ADUs Y/N, ADUs } \\
\text { as LIH }\end{array}$ & $\begin{array}{c}\text { Quantified Objectives in } \\
\text { the 2007-2014 } \\
\text { Housing Plans }\end{array}$ \\
\hline $\begin{array}{l}\text { What conditions influence a } \\
\text { city's ADU production? }\end{array}$ & $\begin{array}{l}\text { Negative Binomial } \\
\text { Regression }\end{array}$ & $\begin{array}{l}\text { Response Variable: } \\
\text { ADU Production }\end{array}$ & $\begin{array}{l}\text { Evaluation of the } \\
\text { 2007-2014 Housing Plans } \\
\text { that were located in the } \\
\text { 2015-2023 Housing Plans }\end{array}$ \\
\hline
\end{tabular}

Data

For all regression tests, development constraints was the experimental variable. College, compliance, density, income, renters, and senior citizens were control variables. Data sources were the cities, COGs, CAHCD, California's Community Colleges Chancellor's Office (CACCCO), the U.S. Bureau of Census (Census), and the Department of Education's Institute of Education Sciences (IES). The COGs are as follows: Association of Bay Area Governments (ABAG), Sacramento Area Council of Governments (SACOG), San Diego Association of Governments (SANDAG), and Southern California Council of Governments (SCAG).

Development constraints measured whether a city's ADU development standards required excessive lot-size, enclosed parking, and/or a deed restriction, as noted by previous studies $[4,43,75,78]$. For example, Beverly Hills required excessive lot-size, Mill Valley required excessive lot-size and deed restrictions, and Pacifica required excessive lot-size, deed restrictions, and enclosed parking, whereas San Ramon did not require any of these standards. Due to model parsimony, these restrictions were transformed into an index reflecting the intensity of the identified ADU zoning restrictions (i.e., a score in the range of $0,0.33,0.66$, and 1; Table 1). College measured the presence of any two- or four-year public/private college or university (CACCCO, IES) in the city because California allows cities to classify college students as low-income households. For-profit institutions were excluded because they primarily serve adult students who hold full-time positions and do not relocate. Compliance measured how each city's housing plan complied with the Housing Element Law (CAHCD) in the nine years prior (1998-2006) to the period of study (2007-2014). This measurement should indicate a city's evidence of planning for current and future housing needs. After examining each 
city's 1998-2006 annual compliance status, the data was averaged. Density measured the density of housing units per square mile of a city's land area (CENSUS). Cities with low density should be more likely to accommodate potential ADUs due to the prevalence of single-family homes and/or land available from large parcels. In addition, California requires each city's housing plan to identify sites with appropriate densities to accommodate current and future housing needs.

Income measured each city's MHI and was transformed by dividing each value by 1000 to ease interpretation (CENSUS). Cities with higher incomes should be more likely to count ADUs overall and ADUs as low-income housing rather than approve multifamily housing that may contain low-income households. Due to parsimony, the study employs this single measure of income to increase the model's linearity and explanatory power rather than dichotomous measures. Renters measured each city's proportion of occupied rental units in relationship to total occupied housing units (CENSUS) and senior citizens measured each city's proportion of persons older than 65 years in relation to a city's population (CENSUS). California requires its cities to quantify and plan the housing needs of both renters and senior citizens. All Census data is year 2000, as these statistics were employed by planners when they created the examined 2007-2014 housing plans. In other models, the following variables were tested and excluded because they were collinear or non-significant: distance (miles between the city hall of each examined city and its central city), political will (general law or charter), and poverty (proportion of households in poverty). Table 3 provides a data summary, and the Supplementary lists all data references.

Table 3. Descriptive statistics of the inferential data. Notes: ADU = accessory dwelling unit, $\mathrm{LIH}=$ low-income housing, $\mathrm{SD}=$ standard deviation, $\mathrm{Y} / \mathrm{N}=$ yes or no.

\begin{tabular}{ccccc}
\hline Variable & Minimum & Maximum & Mean & SD \\
\hline College & 0 & 1 & 0.263 & 0.444 \\
Compliance & 0.125 & 1 & 0.616 & 0.236 \\
Density & 275 & 12,821 & 1805.80 & 1790.22 \\
Development Constraints & 0 & 1 & 0.357 & 0.308 \\
Income & 35,520 & 116,200 & 68,670 & 23,700 \\
Renters & 0.048 & 0.784 & 0.349 & 0.144 \\
Senior Citizens & 0.046 & 0.208 & 0.117 & 0.037 \\
ADUs Y/N & 0 & 1 & 0.561 & 0.501 \\
ADUs as LIH & 0 & 1 & 0.474 & 0.504 \\
Potential ADUs & 0 & 72 & 15.65 & 19.13 \\
ADU Production & 0 & 200 & 13.14 & 30.95 \\
\hline
\end{tabular}

\section{Results}

5.1. Are the Fair-Share Housing Allocations Proportionally Similar for Cities Classified as Low-, Moderate-, or High-Income?

Table 4 indicates the proportions of the sample's allocated housing needs are not similar. The statistics indicate that high-income cities must accommodate $69 \%$ of current and future housing needs as low-income, whereas both moderate- and low-income cities must, respectively, accommodate $60 \%$ and $58 \%$. These proportions appear equitable, with high-income cities proportionally providing more low-income housing and, by extension, increased access to better schools and employment opportunities. An analysis of the collective housing needs allocations for the urban regions indicates a similar equitable approach (e.g., $58 \%$ of housing needs as low-income, $42 \%$ of housing needs as market-rate. Supplementary Table S3). However, equity dissipates upon examination of the quantities of low-income needs. 
Table 4. The fair-share housing needs allocations for the sample by group (proportion and housing needs). The allocation covers the period of study (2007-2014). Sources: [151-154].

\begin{tabular}{cccccc}
\hline \multirow{2}{*}{ Group } & \multicolumn{2}{c}{ Allocation by Proportion } & \multicolumn{2}{c}{ Allocation by Housing Needs } \\
\cline { 2 - 6 } & Low-Income & Market-Rate & Low-Income & Market-Rate & Total \\
\hline Low-Income Cities & $58 \%$ & $42 \%$ & 35,616 & 26,230 & 61,936 \\
Moderate-Income Cities & $60 \%$ & $40 \%$ & 16,034 & 10,627 & 26,661 \\
High-Income Cities & $69 \%$ & $31 \%$ & 11,547 & 5107 & 16,654 \\
& \multicolumn{2}{c}{ Total } & 63,197 & 42,054 & 105,251 \\
\hline
\end{tabular}

Table 4 indicates that the sample was quantitatively allocated 63,197 low-income housing needs, with low-income cities absorbing $56 \%$ of these needs, moderate-income cities absorbing $25 \%$, and high-income cities absorbing only $18 \%$. An analysis of the collective housing needs allocations for the urban region indicates a similar inequity. Figure 1 indicates that cities with MHIs of less than $\$ 50,000$ (circa 2000) must accommodate nearly 60\% (or 312,198/524,050) of the region's low-income housing needs, whereas cities with MHIs higher than $\$ 70,000$ accounted for roughly $16 \%$ (or $82,574 / 524,050$ ) of the region's low-income housing needs. Due to these absorption rates for both the sample and the urban regions, one could argue that California places low-income housing in communities with lower land costs and with greater quantities of low-income households. Ideally, this intervention would improve these communities' housing options through construction or rehabilitation programs. For example, Deng's study of low-income tax credit housing in Miami-Dade County indicated that the tax-credit units were the first significant production of housing in her examined low-income African-American census tracts [155]. On the other hand, one could also argue that these fair-share allocations may concentrate the poor in lower-income cities.

Regarding housing growth, the sample's overall allocation was 105,251 housing needs, with low-income cities absorbing $59 \%$ of overall housing growth, in contrast to $25 \%$ for moderate-income cities and 16\% for high-income cities. Supplementary Figures S2 and S3, which refer to the urban regions, similarly indicate that the collective housing needs allocations for the urban regions directed $61 \%$ of housing growth toward the cities with MHIs of less than $\$ 50,000$ and roughly $15 \%$ of the region's housing growth was directed to cities with MHIs higher than $\$ 70,000$. By directing the bulk of the sample's (as well as the urban regions') housing growth to cities with lower incomes, California may expose lower-income communities to gentrification and may allow higher-income cities to evade transforming their "older, existing single-family detached housing stock [to] zoning for multi-family apartments" [156,157]. 


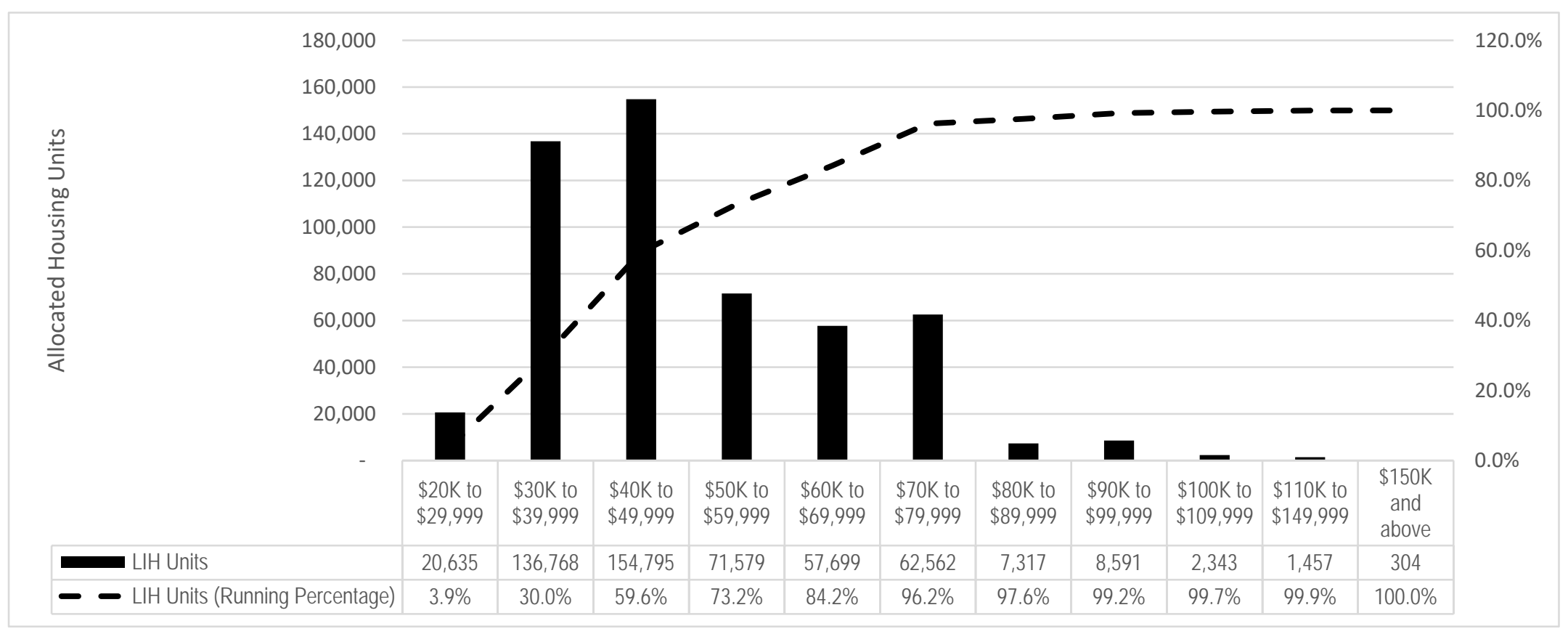

Figure 1. Distribution of the collective low-income housing needs allocations for the urban regions (i.e., Los Angeles, Sacramento, San Diego, and Sacramento; 2007-2014) and categorized by each city's year 2000 median household income (MHI). This table indicates that cities with MHIs between $\$ 20,000-49,999$ received 59.6\% (or 312,198/524,050) of allocated low-income housing needs, whereas cities with MHIs higher than $\$ 70,000$ received roughly $16 \%$ (or $82,574 / 524,050$ ) of allocated low-income housing needs. Sources: ABAG, SACOG, SCAG, SANDAG, U.S. Census Bureau. 


\subsection{To What Extent Do Cities Count Potential ADUs towards Overall or Low-Income Housing Needs?}

Table 5 indicates that $82 \%$ of high-income cities counted potential ADUs towards overall housing needs, in contrast to $50 \%$ of moderate-income cities and $40 \%$ of low-income cities. Regarding ADUs as low-income housing, Table 4 also indicates that $76 \%$ of high-income cities counted ADUs towards low-income housing needs, in contrast to $45 \%$ of moderate-income cities and $25 \%$ of low-income cities. While these potential ADUs were positioned to only satisfy $1.4 \%(892 / 63,197)$ of the sample's low-income housing needs, high-income cities accounted for nearly $45 \%(403 / 892)$ of these ADUs, in contrast to moderate-income cities at 30\% (271/892) and low-income cities at 24\% (218/892). The diminutive proportion of potential ADUs as low-income housing in low-income cities $(0.61 \%$ or $218 / 35,616$ ) suggests that these cities employ many planning tools (e.g., mixed-use, transit-oriented development, overlays, residential rehabilitation, increased density) to not only accommodate their large allocation of low-income housing needs but also regional housing growth [158,159]. For example, Ramsey-Musolf's recent study of housing plans from Los Angeles and Sacramento region cities determined that planners employed 42 different planning tools to accommodate low-income housing needs ([92], Supplementary Table S3).

Table 5. Designation of potential towards ADUs overall or low-income housing needs. This table indicates that $82 \%$ of high-income cities counted potential ADUs overall and $76 \%$ of high-income cities counted potential towards ADUs low-income housing needs. In contrast, $40 \%$ of low-income cities counted potential ADUs overall and $25 \%$ of low-income cities counted potential ADUs towards low-income housing needs. Notes: ADU = accessory dwelling unit, LIH = low-income housing.

\begin{tabular}{cccc}
\hline & $\begin{array}{c}\text { Cities Counting } \\
\text { Potential ADUs }\end{array}$ & $\begin{array}{c}\text { Cities Counting } \\
\text { Potential ADUs as LIH }\end{array}$ & $\begin{array}{c}\text { Potential ADUs as LIH } \\
\text { to Total LIH by Group }\end{array}$ \\
\hline Low-Income Cities & $40 \%($ or $8 / 20)$ & $25 \%($ or $5 / 20)$ & $0.61 \%($ or $218 / 35,616)$ \\
Moderate-Income Cities & $50 \%($ or $10 / 20)$ & $45 \%($ or $9 / 20)$ & $1.69 \%($ or $271 / 16,034)$ \\
High-Income Cities & $82 \%$ or $14 / 17)$ & $76 \%($ or $13 / 17)$ & $3.49 \%($ or $403 / 11,547)$ \\
Total & $57 \%$ or $32 / 57)$ & $47 \%$ or $27 / 57)$ & $1.41 \%($ or $892 / 63,197)$ \\
\hline
\end{tabular}

5.3. What Was the Efficacy of a City's Count of Potential ADUs towards Overall or Low-Income Housing Needs?

Table 6 indicates that the sample counted 892 potential ADUs in which planners designated 749 as low-income and 142 as market-rate housing. Regarding overall efficacy of counting potential ADUs, the sample attained an efficacy of 90\% because the 2015-2023 housing plans indicated that 759 ADUs were constructed. Regarding the efficacy of counting potential ADUs as low-income housing, the sample achieved a $0 \%$ efficacy because the housing plans provided no information that indicated that the constructed ADUs were regulated in terms of the ADU's maximum rent, occupant income, or effective period. Without these covenants, it is not clear that these ADUs will be priced or available to low-income households. Furthermore, the low-income ADU efficacy was worse than the sample's overall performance. Table 7 indicates the sample was allocated 105,251 housing needs. According to the 2015-2023 housing plans and California Department of Finance data, the sample achieved a 67\% efficacy toward overall housing needs, a 139\% efficacy towards market-rate housing needs, and in contrast a $20 \%$ efficacy towards low-income housing needs. For this study, the rates of efficacy (in Tables 6 and 7) indicates that in spite of California's aspiration of housing equity, low-income housing production is constrained and market-rate housing abounds. In particular to ADUs, the data suggests that counting potential ADUs does lead to increased housing inventory. The efficacy for each city can be found in Supplementary Table S4. 
Table 6. The sample's efficacy of counting potential ADUs to ADU production. The sample's potential ADUs achieved an efficacy of $90 \%$ for ADUs overall in contrast with a $0 \%$ efficacy for ADUs towards low-income housing. Notes: ADU = Accessory Dwelling Unit.

\begin{tabular}{cccc}
\hline & Potential ADUs & ADU Production & Efficacy \\
\hline ADUs as Low-income Housing & 750 & 0 & $0 \%$ \\
ADUs as Market-Rate Housing & 142 & 759 & $535 \%$ \\
Total & 892 & 759 & $90 \%$ \\
\hline
\end{tabular}

Table 7. The sample's efficacy of allocated housing needs to constructed units. The sample's housing allocation achieved an overall efficacy of $67 \%$, a market-rate efficacy of $139 \%$, and a low-income housing efficacy of $20 \%$ as indicated by the 2015-2023 housing plans and California Department of Finance.

\begin{tabular}{cccc}
\hline & Allocated Housing Needs & Constructed Units & Efficacy \\
\hline Low-Income Housing Needs & 63,197 & 12,516 & $20 \%$ \\
Market-Rate Housing Needs & 42,054 & 58,444 & $139 \%$ \\
Total & 105,251 & 70,960 & $67 \%$ \\
\hline
\end{tabular}

5.4. What Conditions Increase a City's Probability of Counting Potential ADUs towards Overall or Low-Income Housing Needs?

After holding all variables constant at their means, Table 8 (Model 1) indicates that if a city has a college, then its probability of counting potential ADUs towards overall housing needs increases from roughly $40 \%$ to $96 \%$. With income, cities with MHIs near the variable's minimum, mean, and maximum values were respectively $28 \%, 63 \%$, and $94 \%$ more probable to count potential ADUs. Another way of interpreting income is that for every $\$ 1000$ increase in a city's MHI, that city could expect to count one additional potential ADU to satisfy overall housing needs, when all other variables are held constant at their means. Regarding counting potential ADUs towards low-income housing needs, Table 8 (Model 2) indicates positive statistical relationships with college and income. For example, college cities had a higher probability $(75 \%)$ to count potential ADUs towards low-income housing needs than non-college cities (36\%). With income, cities with MHIs near the variable's minimum, mean, and maximum values were respectively $19 \%, 46 \%$, and $85 \%$ more probable to count potential ADUs towards low-income housing needs. 
Table 8. The logistic regression models. In Model 1, cities with colleges were $96 \%$ more probable to count potential ADUs overall. In addition, cities with household incomes close to the mean $(\$ 68,670)$ were $63 \%$ more probable to count potential ADUs overall. In Model 2 , cities with a college were $75 \%$ more probable to count potential ADUs towards low-income housing needs than non-college cities. In addition, cities with household incomes close to the maximum value $(\$ 116,547)$ were $85 \%$ more probable to count potential ADUs towards low-income housing needs. Notes: ADU $=$ accessory dwelling unit, LIH $=$ low-income housing, $\mathrm{SE}=$ standard error, $\mathrm{Y} / \mathrm{N}=$ yes or no; ${ }^{*}=p<0.05,{ }^{* *}=p<0.01,{ }^{* * *}=p<0.001$.

\begin{tabular}{|c|c|c|c|c|c|c|c|c|}
\hline \multirow[b]{3}{*}{ Variable } & \multirow{3}{*}{$\begin{array}{c}\text { Model } 1 \\
\text { B (SE) } \\
\text { Estimate }\end{array}$} & \multicolumn{3}{|c|}{ Probability } & \multirow{3}{*}{$\begin{array}{c}\text { Model } 2 \\
\text { B (SE) } \\
\text { Estimate }\end{array}$} & \multicolumn{3}{|c|}{ Probability } \\
\hline & & \multirow{2}{*}{ Variable $=$ Min } & \multirow{2}{*}{$\bar{x}$} & \multirow{2}{*}{ Variable $=$ Max } & & \multirow{2}{*}{ Variable $=$ Min } & \multirow{2}{*}{$\bar{x}$} & \multirow{2}{*}{ Variable $=$ Max } \\
\hline & & & & & & & & \\
\hline (Intercept) & $\begin{array}{c}4.815 \\
(2.701)\end{array}$ & & & & $\begin{array}{l}-3.052 \\
(2.443)\end{array}$ & & & \\
\hline College & $\begin{array}{c}3.641 * * \\
(1.205)\end{array}$ & 0.399 & & 0.963 & $\begin{array}{l}1.665 * \\
(0.794)\end{array}$ & 0.357 & & 0.748 \\
\hline Compliance & $\begin{array}{l}-1.330 \\
(1.493)\end{array}$ & & & & $\begin{array}{l}-2.074 \\
(1.362)\end{array}$ & & & \\
\hline Density & $\begin{array}{l}-0.0004 \\
(0.0004)\end{array}$ & & & & $\begin{array}{c}-0.0004 \\
(0.0004)\end{array}$ & & & \\
\hline Development Constraints & $\begin{array}{l}-0.041 \\
(1.179)\end{array}$ & & & & $\begin{array}{c}0.140 \\
(1.037)\end{array}$ & & & \\
\hline Income & $\begin{array}{l}0.045 * \\
(0.022) \\
\end{array}$ & 0.278 & 0.634 & 0.938 & $\begin{array}{l}0.040 * \\
(0.020)\end{array}$ & 0.187 & 0.463 & 0.851 \\
\hline Renters & $\begin{array}{c}4.600 \\
(4.383)\end{array}$ & & & & $\begin{array}{c}2.805 \\
(4.036)\end{array}$ & & & \\
\hline Senior Citizens & $\begin{array}{c}10.351 \\
(10.319)\end{array}$ & & & & $\begin{array}{c}6.756 \\
(9.600) \\
\end{array}$ & & & \\
\hline Observations & $n=57$ & & & & $n=57$ & & & \\
\hline Hosmer and Lemeshow $R^{2}$ & 0.34 & & & & 0.24 & & & \\
\hline Cox and Snell $R^{2}$ & 0.37 & & & & 0.28 & & & \\
\hline Nagelkerke $R^{2}$ & 0.50 & & & & 0.38 & & & \\
\hline Model $\chi^{2}(7)$ & $26.41^{* * *}$ & & & & $18.91^{* * *}$ & & & \\
\hline Response Variable & ADUs $\mathrm{Y} / \mathrm{N}$ & & & & ADUs as $\mathrm{LIH}$ & & & \\
\hline
\end{tabular}




\subsection{What Conditions Influenced Each City's ADU Production?}

Table 9 (Model 3) indicates that college, income, and renters maintained positive associations with ADU production, whereas compliance and density maintained negative associations. When all other variables are held constant at their means, Model 3 indicates that if a city has a college, then its expected ADU production will be roughly 14 units. With income, cities with MHIs near the variable's minimum, mean, and maximum values could expect $A D U$ production of roughly two, six, and 23 units, respectively. With renters, cities with a proportion of occupied rental units near the sample's mean and maximum values could expect $A D U$ production of, respectively, six and over 1000 units, an astounding figure. In the sample, the City of West Hollywood's occupied rental statistic is roughly 78\%, which is three standard deviations above the sample mean and roughly 35 points higher than California's value of $43.1 \%$. Omitting West Hollywood reduces college to marginally significant $(p=0.054)$ and transforms the mean and maximum expected counts for renters to eight and 108 units, respectively (Supplementary Table S5).

By contrast, the statistics for compliance indicate that the ADU production for cities with housing plans that were compliant with state housing law in the previous nine years would be lower than cities with non-compliant housing plans. Specifically, cities with compliance statistics near the variable's minimum, mean, and maximum values could expect decreasing ADU production of roughly 22, six, and three units, respectively. In addition, cities that have a high density of housing units per square mile also have low ADU production. Specifically, cities with density statistics near the variable's minimum, mean, and maximum values could also expect decreasing ADU production of roughly 27, six, and no units, respectively. Since the partial regression slope coefficients for renters is large and compliance and density maintain negative associations, Table 6 (Model 4 std) lists the standardized coefficients with the following order of magnitude: renters, density, income, compliance, and college. Regarding magnitude and using absolute values, an increase in renters influences $A D U$ production roughly $1 \%$ more than density, 34\% more than income, 38\% more than compliance, and 41\% more than college.

The data in Table 6 suggests that counting potential ADUs increases ADU production. In order to determine if there is any statistical relationship between these variables, Table 10 (Model 5) includes potential ADUs as a predictive variable. Due to the sample size $(n=57)$ and the consistent non-significance of development constraints, this variable was omitted. Model 5 indicates that density and renters maintain significance, but the inclusion of potential ADUs renders college and income as non-significant. In this analysis, for the cities that did not count potential ADUs towards housing needs, these cities could expect to produce three ADUs. For those cities with counts of potential ADUs near the variable's mean $(\bar{x}=15.65)$, then those cities could expect to produce six ADUs. Lastly, for those cities with values that were close to the respective means of compliance, density, potential ADUs, and renters, they could, respectively, expect roughly six ADUs for each variable. Regarding magnitude, Table 10 (Model $6 \mathrm{std}$ ) indicates that the absolute values for renters and density maintain equal influence on ADU production and these variables are followed by compliance and then potential ADUs.

One goal of this study has been to examine what conditions influence ADU production. As tested in this study, the conditions that planners can influence are renters, density, compliance and potential ADUs [160]. Planners influence the adoption of zoning that allows single-family and multifamily residential uses. Collectively, these residential uses allow rentals and increases the city's density. Planners also create or manage (with consultants) the creation of housing plans that govern their respective cities' compliance with state housing laws. Lastly, and specific to California, planners with knowledge of their respective city neighborhoods can decide whether to count potential ADUs as a locally-controlled strategy to satisfy local housing needs. 
Table 9. The negative binomial regression models. Model 3 contains the full sample and Model 4 (std) contains the standardized coefficients of Model 3. Model 3 indicates that college cities could expect roughly 14 ADUs in contrast to roughly four ADUs for non-college cities. Cities with values that are close to the respective means of compliance, density, median household income, and proportions of renters could respectively expect roughly six ADUs for each variable. Of the five statistically significant variables in Model 4 (std), renters maintained the most influence due to the absolute value of $|0.058|$. Notes: ADU = accessory dwelling unit, $\mathrm{SE}=$ standard error, $\mathrm{STD}=$ standardized; ${ }^{*}=p<0.05,{ }^{* * *}=p<0.001$.

\begin{tabular}{|c|c|c|c|c|c|}
\hline \multirow[b]{3}{*}{ Variable } & Model 3 & \multicolumn{3}{|c|}{ Model 3 Expected Counts of ADU Production } & \multirow{3}{*}{$\begin{array}{c}\text { Model } 4 \text { (std) } \\
\text { B }\end{array}$} \\
\hline & B (SE) & \multirow{2}{*}{ Variable $=$ Min } & \multirow{2}{*}{$\bar{x}$} & \multirow{2}{*}{ Variable $=$ Max } & \\
\hline & Estimate & & & & \\
\hline (Intercept) & $\begin{array}{l}-2.187 \\
(1.548)\end{array}$ & & & & \\
\hline College & $\begin{array}{l}1.120 * \\
(0.505)\end{array}$ & 4.44 & & 13.61 & $|0.016|$ \\
\hline Compliance & $\begin{array}{c}-2.130 * \\
(0.892)\end{array}$ & 22.42 & 5.96 & 2.66 & $|-0.019|$ \\
\hline Density & $\begin{array}{c}-0.001 * * * \\
(0.0003)\end{array}$ & 26.67 & 5.96 & 0.0001 & $|-0.057|$ \\
\hline Development Constraints & $\begin{array}{l}-0.275 \\
(0.732)\end{array}$ & & & & \\
\hline Income & $\begin{array}{l}0.031 * \\
(0.012)\end{array}$ & 1.01 & 5.96 & 22.92 & $|0.024|$ \\
\hline Renters & $\begin{array}{c}12.418 * * * \\
(2.754)\end{array}$ & 0.14 & 5.96 & 1322.43 & $|0.058|$ \\
\hline Senior Citizens & $\begin{array}{c}3.851 \\
(6.575)\end{array}$ & & & & \\
\hline Observations & 57 & & & & \\
\hline Log Likelihood & -328.457 & & & & \\
\hline$A I C$ & 346.46 & & & & \\
\hline Model $\chi^{2}(7)$ & $32.57^{* * *}$ & & & & \\
\hline Response Variable & ADU Production & & & & \\
\hline
\end{tabular}

Table 10. The negative binomial regression models. Model 5 includes potential ADUs and contains the full sample. Model 5 indicates that cities could expect roughly four ADUs when their count of potential ADUs is zero, six ADUs when their count of potential ADUs is near the mean, and roughly 26 ADUs when the count of potential ADUs is near the maximum value of 72 . Model 6 (std) contains the standardized coefficients of Model 5. Of the four statistically significant variables, Density and Renters maintained equal influence due to their respective absolute values. Notes: ADU $=$ accessory dwelling unit, $\mathrm{SE}=$ standard error, STD = standardized; ${ }^{*}=p<0.05,{ }^{* *}=p<0.01,{ }^{* * *}=p<0.001$.

\begin{tabular}{|c|c|c|c|c|c|}
\hline \multirow[b]{3}{*}{ Variable } & \multirow{3}{*}{$\begin{array}{c}\text { Model } 5 \\
\text { B (SE) } \\
\text { Estimate }\end{array}$} & \multicolumn{3}{|c|}{ Model 5 Expected Counts of ADU Production } & \multirow{3}{*}{$\begin{array}{c}\text { Model } 6 \text { (std) } \\
\text { B }\end{array}$} \\
\hline & & \multirow{2}{*}{ Variable $=$ Min } & \multirow{2}{*}{$\bar{x}$} & \multirow{2}{*}{ Variable $=$ Max } & \\
\hline & & & & & \\
\hline (Intercept) & $\begin{array}{l}-1.250 \\
(1.407)\end{array}$ & & & & \\
\hline College & $\begin{array}{c}0.584 \\
(0.564)\end{array}$ & & & & \\
\hline Compliance & $\begin{array}{c}-2.049 * \\
(0.856)\end{array}$ & 20.18 & 5.65 & 2.60 & $|-0.018|$ \\
\hline Density & $\begin{array}{c}-0.001 \text { ** } \\
(0.0003)\end{array}$ & 20.71 & 5.65 & .0005 & $|-0.049|$ \\
\hline
\end{tabular}


Table 10. Cont.

\begin{tabular}{|c|c|c|c|c|c|}
\hline \multirow[b]{3}{*}{ Variable } & \multirow{2}{*}{$\begin{array}{c}\text { Model } 5 \\
\text { B (SE) }\end{array}$} & \multicolumn{3}{|c|}{ Model 5 Expected Counts of ADU Production } & \multirow{3}{*}{$\frac{\text { Model } 6 \text { (std) }}{\text { B }}$} \\
\hline & & \multirow{2}{*}{ Variable $=$ Min } & \multirow{2}{*}{$\bar{x}$} & \multirow{2}{*}{ Variable $=$ Max } & \\
\hline & Estimate & & & & \\
\hline Income & $\begin{array}{c}0.017 \\
(0.012)\end{array}$ & & & & \\
\hline Potential ADUs & $\begin{array}{l}0.027^{*} \\
(0.013)\end{array}$ & 3.68 & 5.65 & 26.37 & [0.017] \\
\hline Renters & $\begin{array}{c}10.598^{* * *} \\
(2.551)\end{array}$ & 0.232 & 5.65 & 567.43 & $|0.049|$ \\
\hline Senior Citizens & $\begin{array}{c}2.979 \\
(6.205)\end{array}$ & & & & \\
\hline Observations & 57 & & & & \\
\hline Log Likelihood & -324.437 & & & & \\
\hline AIC & 342.44 & & & & \\
\hline Model $\chi^{2}(7)$ & $41.52 * * *$ & & & & \\
\hline Response Variable & ADU Production & & & & \\
\hline
\end{tabular}

\section{Discussion}

This study examined a stratified random sample of California cities in order to determine what conditions influence ADU production and the analyses presented a series of results that require further discussion, but are limited to the sample. California transmits housing needs allocations to each city as an intervention to provide housing equity to all residents. The allocations regionally redistribute low-income housing needs and housing growth. The study determined that the sample's fair-share housing needs allocations required high-income cities to proportionally accommodate more low-income housing needs than moderate- or low-income cities. By contrast, the housing allocations directed large quantities of low-income housing needs and housing growth towards lower-income cities. Table 1 documents the substantial housing needs allocations for the low-income cities of Chula Vista, Hesperia, and Lake Elsinore in contrast to the lighter loads for the high-income cities of Los Gatos, Ross, Pleasanton, Tiburon, and Villa Park. As noted by Baer, California's allocations may actually grandfather the low-density sins of the older built-out communities, while newer cities and cities with access to land must pay for those sins with higher densities [156]. However, two points should be considered.

First, the sample cities responded to allocations from multiple COGs, with each COG employing a unique allocation methodology. Second, the sample contains only 57 cities, not each region's population of cities. In response to these limits, this study also analyzed the fair-share housing needs allocations for the examined urban regions, both collectively and individually. In either case, the analysis of this regional data confirmed a proportional fair-share intent with $60 \%$ of housing needs apportioned to low-income households, but the allocations also directed high quantities of low-income housing needs and housing growth to lower-incomes cities. While the Los Angeles and San Francisco COGs have published reports that quantify housing permits issued in relation to their housing allocations, these reports do not detail the production of low-income housing units, the spatial distribution of allocated housing needs, or the distribution of allocated housing needs by a city's median household income [161,162]. An examination of these additional measures would allow scholars and housing activists to evaluate the equity embedded in a fair-share housing needs allocation at the allocation's onset.

This paper argued that allowing cities to count potential ADUs towards low-income housing needs was California's Faustian Bargain because of the lack of agency oversight and the unproven efficacy of counting potential ADUs as low-income housing. This study determined that 32 cities (or 56\%) counted potential ADUs to satisfy overall housing needs and 27 cities (or $47 \%$ ) counted 
potential ADUs towards low-income housing needs. However, there was no evidence that these cities' zoning standards could impose low-income covenants for ADUs. If a city's zoning code is silent, then it is unlikely that the city can legally enforce such low-income conditions. The housing plans indicated that 759 ADUs were constructed during the period of study and these units represent a $90 \%$ (or 759/842) efficacy of counting potential ADUs towards overall housing needs. However, the plans did not provide any evidence that the constructed ADUs were priced-for or available-to low-income households. This deficiency represents a $0 \%$ efficacy for counting potential ADUs towards low-income housing needs. In addition, the analysis also compared the ADU efficacy to the sample's housing production efficacy and found dissimilar patterns: $20 \%$ for low-income housing needs, $139 \%$ for market-rate housing needs, and $67 \%$ for overall housing needs. A few reasons can explain the differences in efficacy.

Regarding the sample's 20\% efficacy for low-income housing needs, in 2010 California terminated redevelopment tax-increment finance during a budgeting shortfall. When redevelopment agencies were active, these agencies must set-aside $20 \%$ of tax increment funds for low-income housing programs. Many housing plans listed low-income housing projects and programs that were terminated due to a lack of redevelopment funding (e.g., Fountain Valley, Hesperia, San Pablo, and San Ramon). Regarding the sample's 139\% efficacy for market-rate housing needs, twenty cities achieved $100 \%$ or more of their allocated market-rate housing needs. Of that subset, the average MHI was $\$ 73,749$, with only six cities maintaining MHIs that were below $\$ 50,000$. This subset of twenty cities exceeded their allocated market-rate housing needs due to their lower quantities of allocated housing growth. Regarding the sample's 67\% efficacy for overall housing needs, the period of study covers 2007-2014 and this period coincides with the great housing recession (e.g., 2006-2013). In addition, the sample's overall housing needs consisted of $60 \%$ as low-income housing. The deficit of low-income housing production reduced to the sample's overall efficacy.

Regarding the $84 \%$ efficacy for potential ADUs overall, homeowners financed and produced these units and were not reliant on government funding. The primary source of funding for ADU production was the equity in the homeowner's residence. As noted in the research, homeowners construct ADUs for additional income and ADU rent could be used to qualify for ADU production loans [116]. In addition, many units were created through amnesty programs that legalized informal units with permits (e.g., Daly City, Encinitas, Lafayette, Los Gatos, Ojai, Petaluma, and San Carlos). Regarding the $0 \%$ efficacy for ADUs as low-income housing, CAHCD should assert its agency power and remedy this issue. At present, CAHCD oversees the evaluation of nearly 535 housing plans with a limited staff. However, the agency staggers its review of housing plans by region. When CAHCD finds that any city has counted potential ADUs towards low-income housing needs, then the agency should require that the city provide evidence of low-income covenants that will regulate the ADUs maximum rent, occupant-income, or effective period. If there is no legal evidence, then CAHCD should shift the city's count of potential low-income ADUs to market-rate units and then direct the city to implement other planning tools to satisfy the outstanding low-income housing needs. This modification in administrative procedures should close the loophole of California's Faustian Bargain. Closing this loophole is especially important in light of the recent 2017 ADU mandate revisions and the subsequent increase in ADU applications.

In order to determine whether ADUs are suitable as low-income housing, this study call for research on verified and permitted low-income ADUs in light of California's rising housing costs. If low-income ADUs persist, then what was the legal mechanism? If these units did not persist, then what should planners do differently? The City of Santa Cruz is a case in point. From 1986 to 2017, Santa Cruz approved 444 ADUs and restricted 13.5\% (or 60) of those units as low-income housing [68]. However, only 29 low-income ADUs persist because the homeowners have repaid the waived fees that initially restricted the ADU's maximum rent. Furthermore, in 2015, Santa Cruz proposed income and occupancy limitations on ADUs due to the rise of the sharing economy [163-165]. However, the council encountered strong resistance from homeowners, who insisted that unregulated ADU 
income was necessary to supplement homeowner income. These points do not bode well for the cities of Piedmont, CA, USA or Pasadena. In their response to the 2017 ADU mandate revisions, both cities are experimenting with ADUs as low-income housing. Piedmont recently modified its city's zoning code and can impose low-income covenants on ADUs. In Pasadena, the city aimed to incentivize ADU production by reducing permit fees from roughly $\$ 20,000$ to $\$ 1000$ per unit if the homeowner agrees to a seven-year ADU rent restriction [166]. Only time will tell whether Piedmont or Pasadena is successful in increasing the housing options for low-income households.

This study explored the conditions that influence the implementation of ADUs in California cities and the regression tests indicated that sample cities with colleges and high household incomes were positively associated with counting potential ADUs towards overall housing needs and ADUs as low-income housing. Regarding colleges the positive associations were not surprising, given that the following cities classified students as low-income households, described ADUs as student housing, and/or identified working with their respective colleges to increase student housing on campus or within the city itself: Davis (UC Davis), Moraga (Saint Mary's College), Palo Alto (Stanford University), Pleasant Hill (Diablo Valley Junior College), San Marcos (California State University San Marcos), San Pablo (Contra Costa College), and Santa Clara (Santa Clara University, Mission College).

The positive consistency of income, however, seems to conflict with the literature, which maintains that high-income cities resist low-income housing. However, this prevalence is not a conflict if you adopt a California city's view. In California, housing demand is constant. Due to the Housing Element Law and the ADU mandate, cities must accommodate low-income households and counting potential ADUs procedurally satisfies low-income housing needs and complies with state law. From an exclusionary view, which of the following is worse: counting a potential ADU occupied by one household or zoning multifamily land to facilitate an apartment building that would be occupied by multiple households that may require increased educational and social services? I suggest that counting a potential ADUs as low-income housing is more favorable to exclusionary cities than potential apartments. As a result, these cities may take a calculated risk owing to CAHCD's lenient assessment of potential ADUs as per the housing plans for the cities of Folsom, Malibu, Moraga, San Marcos, and San Ramon.

Regarding the significant variables that were negatively associated with ADU production, density was understandable but compliance was a surprise. Regarding density, California allows ADUs on all residentially zoned land. However, many cities restrict ADUs to single-family residential zones, as found in the sample. Thus, density's negative relationship is understandable given that cities with higher overall densities would be unlikely to allow ADUs along with other zoning requirements for multifamily housing units (e.g., open space per unit, sprinklers, occupant and guest parking, design review, stormwater retention). A notable exception is the City of San Francisco, which prohibited ADUs from 1982 to 2016.

Regarding compliance, the negative relationship suggests that cities that adhered to state law and provided suitable zoning to facilitate housing production for roughly $5 \frac{1}{2}$ years (out of nine years) may have delivered suitable housing for various households in all economic segments. In turn, these cities may have lessened their dependence on ADUs to satisfy housing needs. Four points support this assertion. First, the collective fair-share housing allocations in the examined urban regions directed $60 \%$ of housing growth to cities with MHIs of less than $\$ 50,000$. Second, the sample's lower-income cities were less likely to count potential ADUs overall and as low-income. Third, Ramsey-Musolf's recent study determined that California cities employed a wide variety of planning tools to accommodate housing needs. In that study, the top five planning tools were zoning (adoption and/or amendments), residential rehabilitation to remove defects, identification of sites with appropriate densities, identification of sites for transitional housing (e.g., homeless, women's, or emergency shelters) and, modification of development standards to facilitate production [92]. Lastly, the sample's low-income cities' housing plans averaged the highest compliance rates at 67\% (or roughly 
compliant for 6 out of 9 years). Thus, the sample's lower-income cities may have implemented multiple planning tools to accommodate not only regional housing growth but also low-income housing needs.

Regarding potential ADUs, this is the first study that has quantified and tested this variable as it relates to $A D U$ production. The analysis indicates that potential ADUs are positively associated with increased $A D U$ production. This analysis suggests that when planners count potential ADUs, this planning exercise is more influential on ADU production than the city's MHI or the presence of a college, for this sample. Given the research that calls for flexible ADU zoning [3,18,52,78], this study provides evidence that supports California's 2017 revisions to the ADU mandate. These revisions should motivate planners to increase the housing options for diverse households and as a side benefit, ADUs will provide additional income for homeowners.

Regarding the significant variables associated with ADU production, the direction and magnitude of Renters is interesting given the negative relationship of density, which describes the city's housing fabric. In this study, Renters measures the proportion of occupied rented housing units; however, that statistic includes a variety of housing types (e.g., single-family, duplex, triplex, four units and higher). Therefore, each city's renters statistic may measure both rented multifamily units and single-family homes. As noted by Pfeiffer, moderate-incomes cities that desired to be "dynamic and environmentally sustainable" have positioned ADUs as a method to capture the housing market segment that wants to live in "in denser, diverse and more walkable communities" [45]. When renters and density are coupled with potential ADUs, one might suggest that when cities plan for rental housing, this planning effort also creates opportunities for ADU production because these cities have embraced housing diversity and growth. Lastly, this paper argued that the sample's California cities have imposed discretionary authority via development constraints, but this variable was not significant in any test. Even though Table 1 indicates that $70 \%$ of the sample maintained at least one constraint, the measurement in this study relied on current zoning. Therefore, the tested variable may have not have been in effect during the study period.

\section{Conclusions}

In summary, California requires all cities to accommodate housing demand and employs a fair-share housing allocation scheme to quantify and redistribute housing needs. Beginning in 1982, California allowed ADUs as housing units, and as of 2003, ADUs could be counted towards low-income housing needs. This study argued that counting potential ADUs as low-income housing was California's Faustian Bargain due to a lack of state and city oversight and the unproven efficacy of counting potential ADUs as low-income housing. This research examined a stratified random sample of 57 California cities and found that the sample's fair-share housing needs allocations advanced a fair-share intent; however, the quantities of low-income units might re-concentrate the poor in lower-income cities. In addition, the quantities of housing growth directed towards lower-income cities may expose these cities to gentrification. The analysis indicated that many of the sample cities counted potential ADUs towards low-income housing needs, but none of these cities maintained zoning standards that would legally secure these units as long-term, low-income housing. In addition, the analysis determined that $90 \%$ of the counted potential ADUs were constructed, but none of these units could be verified as low-income housing. The inferential tests indicated that the sample's cities with colleges and high household incomes were consistently associated with counting potential ADUs towards overall and towards low-income housing needs. Surprisingly, a city's count of potential ADUs, as well as cities with high proportions of renters, were positively associated with ADU production, whereas a city's density and previous compliance with state housing law were associated with decreased ADU production. Of the tested variables, a city's proportion of renters and density were the most influencing variables on ADU production. These variables suggest that when cities support diverse housing options for diverse housing needs, a high proportion of renters might signal that these cities might also support ADU production. In 2017, California removed many zoning restrictions on ADU production in order to increase housing inventory. News reports suggest that homeowners will 
increase ADU production and consequently, planners will continue to count potential ADUs towards housing needs. However, unless California revises its procedures, it remains to be seen whether ADUs as regulated and available low-income housing will be produced in accordance with the counts of potential low-income ADUs that are found in many compliant housing plans.

Supplementary Materials: The following are available online at http:/ / www.mdpi.com/2413-8851/2/3/89/s1. The dataset for this study can be found at https://scholarworks.umass.edu/larp_datasets/.

Funding: This research was funding in part by a Faculty Excellence Grant given by the UMass Amherst Department of Landscape Architecture and Regional Planning.

Acknowledgments: I thank Joe Colombo, Community Development Director for the City of Hawaiian Gardens, CA (USA), and Stan Wong, former Director of Planning and Redevelopment at the City of Glendora, CA (USA), for their guidance in my years as a planning practitioner. I would also thank Katrin Anacker, Kirk McClure, Melinda McCoy (CAHCD), and Paul McDougall (CAHCD) for comments on early drafts; Jessica Pearlman and Andrea Cataldo from UMass Amherst ISSR for statistical assistance, and the three anonymous reviewers for their helpful comments. Lastly, any mistakes found in the research are my own.

Conflicts of Interest: The author declares no conflict of interest.

\section{References}

1. Second Unit Law; California Government Code; California Government: Sacramento, CA, USA, 1982.

2. Andrews, J. Not Your Grandmother's Granny Flat. Planning 2005, 68, 8-9.

3. Chapple, K.; Wegmann, J.; Nemirow, A.; Dentel-Post, C. Yes in My Backyard: Mobilizing the Market for Secondary Units; University of California Transportation Center: Berkeley, CA, USA, 2011.

4. Mukhija, V.; Cuff, D.; Serrano, K. Backyard Homes \& Local Concerns: How Can Local Concerns Be Better Addressed? University of California: Los Angeles, CA, USA, 2014.

5. Baer, W.C. California's Fair-Share Housing 1967-2004: The Planning Approach. J. Plan. Hist. 2008, 7, 48-71. [CrossRef]

6. Housing Element Law; California Government Code; California Government: Sacramento, CA, USA, 1967; Chapter 1658.

7. 5th Cycle Annual Progress Report Permit Summary; CA Department of Housing and Community Development: Sacramento, CA, USA, 2018. Available online: http:/ /www.hcd.ca.gov/community-development/housingelement/index.shtml\#annual (accessed on 15 September 2018).

8. Chapple, K. "Hidden" Density: The Potential of Small-Scale Infill Development; Institute of Urban and Regional Development: Berkeley, CA, USA, 2011.

9. Daniels, T.L. Zoning for Accessory Housing. In Zoning Practice; American Planning Association: Chicago, IL, USA, 2012; Volume 7, pp. 2-7.

10. 2015-2023 Housing Element of the General Plan; City of Santa Cruz: Santa Cruz, CA, USA, 2015.

11. Rudel, T.K. Household change, accessory apartments, and low income housing in suburbs. Prof. Geogr. 1984, 36, 174-181. [CrossRef]

12. Brown, M.J.; Palmeri, J. Accessory Dwelling Units in Portland, Oregon; Evaluation and Intepretation of a Survey of ADU Owners; Oregon Department of Environmental Quality: Portland, OR, USA, 2014.

13. Talen, E. Prospects for walkable, mixed-income neighborhoods: Insights from U.S. developers. J. Hous. Built Environ. 2013, 28, 79-94. [CrossRef]

14. Chapter 134; California Government Code; California Government: Sacramento, CA, USA, 1943.

15. Chapman, N.J.; Howe, D.A. Accessory apartments: Are they a realistic alternative for ageing in place? Hous. Stud. 2001, 16, 637-650. [CrossRef]

16. Pfeiffer, D.; Tziganuk, A.; Cloutier, S.; Colbert, J.; Strasser, G. Realizing Innovative Senior Housing Practices in the U.S. In Proceedings of the ACSP 57th Annual Conference: Cities, Regions, \& Growth: Smart, Inclusive, Equitable, Denver, CO, USA, 12-15 October 2017.

17. Chapple, K.; Nemirow, A.; Wegmann, J.; Dentel-Post, C. The Potential for Second Units in the East Bay; Institute of Urban and Regional Development: Berkeley, CA, USA, 2013.

18. Ritzdorf, M. Zoning Barriers to Housing Innovation. J. Plan. Educ. Res. 1985, 4, 177-184. [CrossRef]

19. California Government Code. In Zoning; California Government: Sacramento, CA, USA, 2013. 
20. Knauss, N.L. Zoned Municipalities in the United States; U.S. Department of Commerce-Divison of Building and Housing: Washington, DC, USA, 1933.

21. Government Document. Constitution of the United States; Washington, DC, USA, 1787.

22. Hoover, H. A Stadard State Zoning Enabling Act, Revised ed.; U.S. Department of Commerce-Division of Building and Housing: Washington, DC, USA, 1926.

23. Village of Euclid, $\mathrm{OH}$ v. Ambler Realty Co; Supreme Court: Washington, DC, USA, 1926; Volume 272, p. 365.

24. Pendall, R. Opposition to housing-NIMBY and beyond. Urban Aff. Rev. 1999, 35, 112-136. [CrossRef]

25. Nguyen, M.T.; Basolo, V.; Tiwari, A. Opposition to Affordable Housing in the USA: Debate Framing and the Responses of Local Actors. Hous. Theory Soc. 2013, 30, 107-130. [CrossRef]

26. Scally, C.P.; Tighe, J.R. Democracy in Action?: NIMBY as Impediment to Equitable Affordable Housing Siting. Hous. Stud. 2015, 30, 749-769. [CrossRef]

27. Ramsey-Musolf, D. State Mandates, Housing Elements, and Low-income Housing Production. J. Plan. Lit. 2017, 32, 117-140. [CrossRef]

28. Calavita, N.; Grimes, K.; Mallach, A. Inclusionary housing in California and New Jersey: A comparative analysis. Hous. Policy Debate 1997, 8, 109-142. [CrossRef]

29. Bratt, R.G. Overcoming Restrictive Zoning for Affordable Housing in Five States: Observations for Massachusetts; Citizens' Housing and Planning Association: Boston, MA, USA, 2012; p. 192.

30. Graddy, E.A.; Bostic, R.W. The Role of Private Agents in Affordable Housing Policy. J. Public Adm. Res. Theory 2010, 20, I81-I99. [CrossRef]

31. Schuetz, J. No Renters in My Suburban Backyard: Land Use Regulation and Rental Housing. J. Policy Anal. Manag. 2009, 28, 296-320. [CrossRef]

32. Lazarowich, M. (Ed.) Granny Flats as Housing for the Elderly: International Perspectives; Haworth Press: Binghamton, NY, USA, 1991.

33. Antoninetti, M. The Difficult History of Ancillary Units: The Obstacles and Potential Opportunities to Increase the Heterogeneity of Neighborhoods and the Flexibility of Households in the United States. J. Hous. Elder. 2008, 22, 348-375. [CrossRef]

34. Hare, P.H. The Echo Housing/Granny Flat Experience in the US. In Granny Flats as Housing for the Elderly: International Perspectives; Lazarowich, M., Ed.; The Haworth Press: New York, NY, USA, 1991.

35. Public Housing Movable Units. Available online: http://housing.vic.gov.au/public-housing-movable-units (accessed on 18 August 2018).

36. Koebel, T.C.; Beamish, J.; Danielsen-Lang, K.; Steeves, J. Evaluation of the HUD Elder Cottage Housing Opportunity (ECHO) Program; Virginia Center for Housing Research: Blacksburg, VA, USA, 2003.

37. Pollak, P. Rethinking Zoning to Accommodate the Elderly in Single Family Housing. J. Am. Plan. Assoc. 1994, 60, 521-531. [CrossRef]

38. Markovich, J.; Hendler, S. Beyond "Soccer Moms": Feminist and New Urbanist Critical Approaches to Suburbs. J. Plan. Educ. Res. 2006, 25, 410-427. [CrossRef]

39. Gellen, M. Accessory Apartments in Single-Family Housing; Center for Urban Policy Research: New Brunswick, NJ, USA, 1985.

40. Liebig, P.S.; Koenig, T.; Pynoos, J. Zoning, Accessory Dwelling Units, and Family Caregiving. J. Aging Soc. Policy 2006, 18, 155-172. [CrossRef] [PubMed]

41. Myers, D.; Ryu, S. Aging Baby Boomers and the Generational Housing Bubble Foresight and Mitigation of an Epic Transition. J. Am. Plan. Assoc. 2008, 74, 17-33. [CrossRef]

42. Varady, D.P. Factors Affecting Middle-Income Elderly Interest in Accessory Apartment Conversion. J. Arch. Plan. Res. 1988, 5, 81-88.

43. Wegmann, J.; Chapple, K. Understanding the Market for Secondary Units in the East Bay; Institute of Urban and Regional Development: Berkeley, CA, USA, 2012.

44. Orfield, M.W. American Metropolitics: The New Suburban Reality; Brookings Institution: Washington, DC, USA, 2011.

45. Pfeiffer, D. Retrofitting suburbia through second units: Lessons from the Phoenix region. J. Urban. Int. Res. Placemaking Urban Sustain. 2014, 1-23. [CrossRef]

46. Retsinas, J.; Retsinas, N.P. Accessory Apartment Conversion Programs. J. Aging Soc. Policy 1991, 3, 73-89. [CrossRef] [PubMed]

47. Ye, L.; Mandpe, S.; Meyer, P.B. What is "smart growth?"-Really? J. Plan. Lit. 2005, 19, 301-315. [CrossRef] 
48. Arigoni, D. Affordable Housing and Smart Growth: Making the Connection; National Neighborhood Coalition: Washington, DC, USA, 2001; pp. 1-56.

49. Meck, S. (Ed.) Growing Smart Legislative Guidebook: Model Statutes for Planning and the Management of Change; American Planning Association: Chicago, IL, USA, 2002.

50. Mathur, S. Impact of Urban Growth Boundary on Housing and Land Prices: Evidence from King County, Washington. Hous. Stud. 2014, 29, 128-148. [CrossRef]

51. Loukaitou-Sideris, A. Inner-City Commercial Strips: Evolution, Decay: Retrofit? Town Plan. Rev. 1997, 68, 1-29. [CrossRef]

52. Moore, S.A.; Palleroni, S. The Alley Flat Initiative; The University of Texas Center for Sustainable Development: Austin, TX, USA, 2008.

53. Martin, M.D. The case for residential back-alleys: A north American perspective. J. Hous. Built Environ. 2002, 17, 145-171. [CrossRef]

54. Carmon, N. The Phoenix Strategy for updating housing stock: Preventing neighborhood deterioration and promoting sustainable development. J. Am. Plan. Assoc. 2002, 68, 416-434. [CrossRef]

55. Nelson, A.C. Catching the Next Wave: Older Adults and the 'New Urbanism'. Generations 2009, 33, 37-42.

56. Nelson, A.C. Top Ten State and Local Strategies to Increase Affordable Housing Supply; Fannie Mae Foundation: Washington, DC, USA, 2003.

57. Cabrera, J.F.; Najarian, J.C. Can New Urbanism Create Diverse Communities? J. Plan. Educ. Res. 2013, 33, 427-441. [CrossRef]

58. Johnson, J.S.; Talen, E. Affordable Housing in New Urbanist Communities: A Survey of Developers. Hous. Policy Debate 2008, 19, 583-613. [CrossRef]

59. Spivak, J. Making Room for Mom and Dad. Planning 2012, 78, 8-13.

60. Kuhlman, T.; Farrington, J. What is Sustainability? Sustainability 2010, 2, 3436-3448. [CrossRef]

61. Jepson, E.J.; Haines, A.L. Zoning for Sustainability: A Review and Analysis of the Zoning Ordinances of 32 Cities in the United States. J. Am. Plan. Assoc. 2014, 80, 239-252. [CrossRef]

62. Moffat, D. Accessory dwelling units-Santa Cruz, California. Places 2004, 16, 26-29.

63. Brinig, M.F.; Garnett, N.S. A Room of One's Own: Accessory Dwelling Unit Reforms and Local Parochialism. Urban Lawyer 2013, 45, 519 .

64. Sage Computing Inc. Accessory Dwelling Units: Case Study; U.S. Department of Housing and Urban Development: Washington, DC, USA, 2008.

65. Moore, S.A.; Wilson, B.B. Contested Construction of Green Building Codes in North America: The Case of the Alley Flat Initiative. Urban Stud. 2009, 46, 2617-2641. [CrossRef]

66. Atash, F. Local land use regulations in the USA. Land Use Policy 1990, 7, 231-242. [CrossRef]

67. Howe, D.A. The Flexible House Designing for Changing Needs. J. Am. Plan. Assoc. 1990, 56, 69-77. [CrossRef]

68. Mellor, J. Email Communication; City of Santa Cruz Economic Development Office: Santa Cruz, CA, USA, 2018.

69. Wegmann, J.; Mawhorter, S. Measuring Informal Housing Production in California Cities. J. Am. Plan. Assoc. 2017, 83, 119-130. [CrossRef]

70. Caves, R.W. Second Units and Housing Crisis in California. J. Urban Plan. Dev. 1986, 112, 26-36. [CrossRef]

71. Ordinance No. 1797. In National City Code of Ordinances; City Clerk: National City, CA, USA, 1983.

72. Sabatini, J. Supervisors reach compromise to allow in-law units across SF. San Francisco Examiner, 19 July 2016. Available online: http:/ / www.sfexaminer.com/supervisors-reach-compromise-allow-law-units-across-sf/ (accessed on 2 January 2017).

73. Giwargis, R. San Jose eases rules to build granny units to increase housing stock. The Mercury News, 22 November 2016. Available online: http:/ / www.mercurynews.com/2016/11/22/san-jose-eases-rules-tobuild-granny-units-a-new-source-of-affordable-housing/ (accessed on 2 January 2017).

74. Talen, E.; Knaap, G. Legalizing Smart Growth: An Empirical Study of Land Use Regulation in Illinois. J. Plan. Educ. Res. 2003, 22, 345-359. [CrossRef]

75. Cobb, R.; Dvorak, S. Accessory Dwelling Units: Model State Act and Local Ordinance; American Association of Retired Persons, Public Policy Institute: Washington, DC, USA, 2000.

76. Schill, M.H. Regulations and Housing Development: What We know. Cityscape 2005, 8, 5-19.

77. Wegmann, J.; Nemirow, A. Secondary Units and Urban Infill: A Literature Review; Institute of Urban and Regional Development: Berkeley, CA, USA, 2011. 
78. Wegmann, J.; Chapple, K. Hidden density in single-family neighborhoods: Backyard cottages as an equitable smart growth strategy. J. Urban. Int. Res. Placemaking Urban Sustain. 2014, 7, 307-329. [CrossRef]

79. Baer, W.C. The Evolution of Local and Regional Housing Studies. J. Am. Plan. Assoc. 1986, 52, $172-184$. [CrossRef]

80. Lang, R.E. Valuing the Suburbs: Why Some “Improvements" Lower Home Prices. Opolis 2005, 1, 5-12.

81. Chavez, S.; Quinn, J. Substandard housing garages: Immigrants in, cars out. Los Angeles Times. 24 May 1987. Available online: http:/ / articles.latimes.com/1987-05-24/news/mn-2558_1_one-car-garage (accessed on 12 December 2016).

82. Mukhija, V. Outlaw In-Laws: Informal Second Units and the Stealth Reinvention of Single-Family Housing. In The Informal American City: Beyond Taco Trucks and Day Lab; Mukhija, V., Loukaitou-Sideris, A., Eds.; MIT Press: Cambridge, MA, USA, 2014; pp. 39-58.

83. Ward, P.M.; de Souza, F.; Giusti, C.; Larson, J.E. El Titulo en la Mano: The Impact of Titling Programs on Low-Income Housing in Texas Colonias. Law Soc. Inq.-J. Am. Bar Found. 2011, 36, 1-82. [CrossRef]

84. Meck, S.; Retzlaff, R.C.; Schwab, J. Regional Approaches to Affordable Housing; American Planning Association: Chicago, IL, USA, 2003.

85. Von Hoffman, A. The End of the Dream: The Political Struggle of America's Public Housers. J. Plan. Hist. 2005, 4, 222. [CrossRef]

86. Martinez, S.C. The Housing Act of 1949: Its place in the realization of the American dream of homeownership. Hous. Policy Debate 2000, 11, 467-487. [CrossRef]

87. Orlebeke, C.J. The evolution of low-income housing policy, 1949 to 1999. Hous. Policy Debate 2000, 11, 489-520. [CrossRef]

88. Von Hoffman, A. A study in contradictions: The origins and legacy of the Housing Act of 1949. Hous. Policy Debate 2000, 11, 299-326. [CrossRef]

89. Walsh, J.D. Reaching Mrs. Murphy: A Call for Repeal of the Mrs. Murphy Exemption to the Fair Housing Act. Harv. Civ. Rights-Civ. Lib. Rev. 1999, 34, 30.

90. Jun, H.-J. The Link Between Local Comprehensive Plans and Housing Affordability: A Comparative Study of the Atlanta and Detroit Metropolitan Areas. J. Am. Plan. Assoc. 2017, 83, 249-261. [CrossRef]

91. Minimum Standards and Procedures for Local Comprehensive Planning; Georgia Department of Community Affairs: Atlanta, GA, USA, 2014; Volume 110-12-1, p. 10.

92. Ramsey-Musolf, D. According to the Plan: Testing Housing Plan Quality on Low-income Housing Production. Urban Sci. 2018, 2, 1. [CrossRef]

93. Comprehensive Planning; Wisconsin Statutes, Chapter 66; Madison, WI, USA, 1999.

94. Keane, M.J. Wisconsin's Comprehensive Planning Law; Wisconsin Legislative Reference Bureau: Madison, WI, USA, 2015; p. 3.

95. Ohm, B.W.; Merrill, J.; Schmidke, E. Housing Wisconsin: A Guide to Preparing the Housing Element of a Local Comprehensive Plan; University of Wisconsin Extension: Madison, WI, USA, 2000.

96. Affordable Housing Planning and Appeal Act. Illinois Compiled Statutes; Division 67 Chapter 31; Springfield, IL, USA, 2004.

97. Hoch, C. How plan mandates work-Affordable housing in Illinois. J. Am. Plan. Assoc. 2007, 73, 86-99. [CrossRef]

98. Ramsey-Musolf, D. Evaluating California's Housing Element Law, Housing Equity, and Housing Production (1990-2007). Hous. Policy Debate 2016, 26, 488-516. [CrossRef]

99. Palm, M.; Niemeier, D. Achieving Regional Housing Planning Objectives: Directing Affordable Housing to Jobs-Rich Neighborhoods in the San Francisco Bay Area. J. Am. Plan. Assoc. 2017, 83, 377-388. [CrossRef]

100. Hamada, H. 62 Cities in Los Angeles County: Did Regional Housing Needs Assessment (RHNA) Planning Meet State Housing Element Goals? Cal Poly Pomona: Pomona, CA, USA, 2017.

101. California Department of Housing and Community Development. Housing Element Status Reports. Available online: http://www.hcd.ca.gov/community-development/housing-element/index.shtml (accessed on 15 October 2015).

102. Lewis, P.G. Can state review of local planning increase housing production? Hous. Policy Debate 2005, 16, 173-200. [CrossRef]

103. Lewis, P.G. California's Housing Element Law: The Issue of Local Noncompliance; Public Policy Institute of CA: San Francisco, CA, USA, 2003. 
104. Ramsey-Musolf, D. California's Housing Element Law: Evaluating and Predicting Municipal Effort, 1990-2007. Ph.D. Dissertation, University of Wisconsin, Madison, WI, USA, 2013.

105. Schwartz, A. Housing Policy in the United States; Routledge: New York, NY, USA, 2010.

106. Bratt, R.G.; Keating, W.D. Federal Housing Policy and HUD—Past Problems and Future Prospects of a Beleaguered Bureaucracy. Urban Aff. Rev. 1993, 29, 3-27.

107. Connerly, C.E. What should be done with the Public Housing Program. J. Am. Plan. Assoc. 1986, 52, $142-155$. [CrossRef]

108. Accessory Dwelling Unit Regulations. Available online: https://ww5.cityofpasadena.net/planning/ accessory-dwelling-unit-regulations / (accessed on 15 March 2015).

109. The Map Act, Section 66411; California Government Code; California Government: Sacramento, CA, USA.

110. Zoning Districts; City of Pasadena, Pasadena, CA, USA, 2013. Available online: https:/ /www.arcgis.com/ home/item.html?id=2c3295b27e0649a181db3512bf0940d4 (accessed on 15 March 2016).

111. Assessor Parcels-2014 Tax Roll; County of Los Angeles: Los Angeles, CA, USA, 2015. Available online: https:/ / egis3.lacounty.gov/dataportal/2015/03/10/assessor-parcel/ (accessed on 15 January 2017).

112. Willson, R.W. Parking Reform Made Easy; Island Press: Washington DC, USA, 2013.

113. Shoup, D. The high cost of minimum parking requirements. In Parking: Issues and Policies; Ison, S., Mulley, C., Eds.; Emerald Group Publishing Limited: Bingley, UK, 2014; Volume 5, pp. 87-113.

114. Abbott, J. Understanding and Managing the Unknown: The Nature of Uncertainty in Planning. J. Plan. Educ. Res. 2005, 24, 237-251. [CrossRef]

115. Mayer, C.J.; Somerville, C.T. Land use regulation and new construction. Reg. Sci. Urban Econ. 2000, 30, 639-662. [CrossRef]

116. Brown, M.J.; Watkins, T. Understanding and Appraising Properties with Accessory Dwelling Units. Apprais. J. 2012, 80, 297-309.

117. Savin, S. Notice of a Type II Decision on a Proposal in Your Neighborhood; Bureau of Development Services, Land Use Services Division, Ed.; City of Portland: Portland, OR, USA, 2008.

118. Srikrishnan, M. Encinitas Tries to Salvage Failed Granny-Flat Experiment. Voice San Diego, 10 February 2016. Available online: https: / www.voiceofsandiego.org/housing/encinitas-tries-to-salvage-failed-granny-flatexperiment/ (accessed on 15 September 2018).

119. Median Values; U.S. Census Bureau: Washington, DC, USA, 2010.

120. Fryer, A. Secondary units not adequate form of low income housing, Court says. Malibu Surfsider News, 24 March 2015. Available online: http:/ / www.malibusurfsidenews.com/city/secondary-units-notadequate-form-low-income-housing-court-says (accessed on 7 November 2016).

121. Sawicki, J. City of Malibu Loses Low Income Housing Lawsuit. The Malibu Times, 15 March 2015. Available online: http:/ / www.malibutimes.com/news/article_c19a3f80-cd9e-11e4-935b-77baf8a2f4de.html (accessed on 10 November 2016).

122. Trancas PCH, LLC v. City of Malibu; Superior Court of California, County of Los Angeles: Los Angeles, CA, USA, 2015.

123. City of Malibu. 2006-2014 Housing Element; City of Malibu: Malibu, CA, USA, 2013.

124. Penfold, J. Palos Colorados: A Long Time Coming. The Lamorinda Weekly, 14 March 2007.

125. Thissen, P. Palos Colorados gets final approval, but the devil's in the details. East Bay Times, 23 April 2009.

126. Town of Moraga. 2010 Housing Element Update; Town of Moraga: Moraga, CA, USA, 2010; p. 98.

127. Braccini, S. Palos Colorados Finally Get Green Light. The Lamorinda Weekly, 20 April 2016.

128. City of San Ramon. City of San Ramon General Plan, 2007-2014 Housing Element; City of San Ramon: San Ramon, CA, USA, 2009; p. 469.

129. Edwards, P. Affordable Housing Agreement, on Site Affordable Rental Units (Old Summit Ranch); City of San Ramon: San Ramon, CA, USA, 2006.

130. City of San Ramon. City of San Ramon General Plan, 2015-2023 Housing Element; City of San Ramon: San Ramon, CA, USA, 2015; p. 178.

131. City of Folsom. Housing Element: Policy Document and Background Report; City of Folsom: Folsom, CA, USA, 2013; p. 269.

132. Chaddock, D. Folsom targeted in lawsuit. El Dorado Hills Telegraph, 15 April 2011.

133. McCarthy, M. Activists anticipate regional fight over low-income housing. Sacramento Business Journal, 26 May 2002. 
134. City of San Marcos. General Plan, 2005-2010 Housing Element; City of San Marcos: San Marcos, CA, USA, 2005.

135. City of San Marcos. 2013-2021 Housing Element; City of San Marcos: San Marcos, CA, USA, 2013.

136. Talbert, C.T.; Gray, M.S. Curtin's California Land Use and Planning Law, 34th ed.; Solano Press Books: Point Arena, CA, USA, 2014.

137. Hirt, S.A. Zoned in the USA: The Origins and Implications of American Land-Use Regulation; Cornell University Press: Ithaca, NY, USA, 2014; p. 245.

138. Assembly Bill No. 2299; California Government Code; California Government: Sacramento, CA, USA, 2015.

139. Senate Bill No. 1069; Volume California Government Code; California Government: Sacramento, CA, USA, 2015.

140. Assembly Bill No. 2406; California Legislative Office: Sacramento, CA, USA, 2015.

141. Garcia, D. ADU Update: Early Lessons and Impacts of California's State and Local Policy Changes; Terner Center for Housing Innovation, University of California: Berkeley, CA, USA, 2017.

142. Welsh, N. Santa Barbara's Granny Flat Avalanche. Santa Barbara Independent, 27 September 2017. Available online: https://www.independent.com/news/2017/sep/28/santa-barbaras-granny-flat-avalanche/ (accessed on 15 September 2018).

143. Scheinin, R. Affordable Housing 101-Why not build more granny units. The Mercury News, 4 October 2016.

144. Strauss, B. Planning for Second Units Forum; Association of Bay Area Governments: San Francisco, CA, USA, 2003.

145. Thomas, J.M.; Ritzdorf, M. (Eds.) Urban Planning and the African American Community: In the Shadows; Sage: Thousand Oaks, CA, USA, 1997; p. 331.

146. Walsh, S.; Roberts, T.; Pellman, S. California Planning Guide: An Introduction to Planning in California; California Governor's Office of Planning and Research: Sacramento, CA, USA, 2005.

147. American Factfinder; U.S. Census Bureau: Washington, DC, USA, 2000.

148. Ladrón de Guevara, F.; Washington, S.; Oh, J. Forecasting Crashes at the Planning Level: Simultaneous Negative Binomial Crash Model Applied in Tucson, Arizona. Transp. Res. Rec. J. Transp. Res. Board 2004, 1897, 191-199. [CrossRef]

149. Wang, X.; Lindsey, G.; Hankey, S.; Hoff, K. Estimating Mixed-Mode Urban Trail Traffic Using Negative Binomial Regression Models. J. Urban Plan. Dev. 2014, 140. [CrossRef]

150. O’Brien, R. A Caution Regarding Rules of Thumb for Variance Inflation Factors. Qual. Quant. 2007, 41, 673-690. [CrossRef]

151. Southern California Association of Governments. Available online: http://www.scag.ca.gov/about/Pages/ Home.aspx (accessed on 6 June 2014).

152. Association of Bay Area Governments. Available online: http://abag.ca.gov/overview/whowhat.html (accessed on 15 July 2014).

153. Sacramento Area Council of Governments. Available online: http://www.sacog.org/about-sacog (accessed on 7 June 2014).

154. San Diego Association of Governments. Available online: http://www.sandag.org/index.asp?fuseaction= about.home (accessed on 15 July 2014).

155. Deng, L. Low-Income Housing Tax Credit Developments and Neighborhood Change: A Case Study of Miami-Dade County. Hous. Stud. 2011, 26, 867-895. [CrossRef]

156. Baer, W.C. California's Housing Element-A Backdoor Approach to Metropolitan Governance and Regional Planning. Town Plan. Rev. 1988, 59, 263-276. [CrossRef]

157. Blackwell, A.G.; Bell, J. Equitable Development for a Stronger Nation: Lesson from the Field. In The Geography of Opportunity: Race and Housing Choice in Metropolitan America, USA; de Sousa Briggs, X., Ed.; The Brookings Institute: Washington, DC, USA, 2005.

158. Goetz, E.G.; Chapple, K.; Lukermann, B. Enabling Exclusion: The Retreat from Regional Fair Share Housing in the Implementation of the Minnesota Land Use Planning Act. J. Plan. Educ. Res. 2003, 22, 213-225. [CrossRef]

159. Aurand, A. Florida's Planning Requirements and Affordability for Low-Income Households. Hous. Stud. 2014, 29, 677-700. [CrossRef]

160. Dallal, G.E. Which Predictors Are More Important? 2001, Volume 2016. Available online: http://www. jerrydallal.com/LHSP/importnt.htm (accessed on 11 November 2016). 
161. San Francisco Bay Area Progress in Meeting 2007-2014 Regional Housing Need Allocation; Association of Bay Area Governments: San Francisco, CA, USA, 2015.

162. Carreras, J. Housing Element Compliance and Building Permit Issuance in the SCAG Region; Planning and Policy Department, Community Planning Division, Ed.; Southern California Association of Governments: Los Angeles, CA, USA, 2006; p. 46.

163. Short-Term/Vacation Rentals and Accessory Dwelling-Previous Public Correspondence (Ordinance 2015-15); City Clerk, Ed.; City of Santa Cruz: Santa Cruz, CA, USA, 2015.

164. Short-Term/Vacation Rentals and Accessory Dwelling_Public Correspondence (Ordinance 2015-15); City Clerk, Ed.; City of Santa Cruz: Santa Cruz, CA, USA, 2015.

165. Short-Term/Vacation Rentals and Accessory Dwelling-Agenda Report (Ordinance 2015-15); City Clerk, Ed.; City of Santa Cruz: Santa Cruz, CA, USA, 2015.

166. Rivera, F. Council Approves Accessory Dwelling Ordinance. Pasadena Star News, 13 March 2018. Available online: http:/ / www.pasadenanow.com/main/council-approves-accessory-dwelling-ordinance/ \#.WqgbjejwaUk (accessed on 15 March 2018).

(c) 2018 by the author. Licensee MDPI, Basel, Switzerland. This article is an open access article distributed under the terms and conditions of the Creative Commons Attribution (CC BY) license (http://creativecommons.org/licenses/by/4.0/). 